\title{
Controlling interlayer interactions in vanadium pentoxide-poly(ethylene oxide) nanocomposites for enhanced magnesium-ion charge transport \\ and storage
}

\author{
Sanjaya D. Perera ${ }^{1}$, Randall Archer ${ }^{1}$, Craig A. Damin ${ }^{1}$, Rubén Mendoza-Cruz ${ }^{2}$ \\ and Christopher P. Rhodes ${ }^{1 *}$ \\ ${ }^{1}$ Department of Chemistry and Biochemistry, Texas State University, 601 \\ University Drive, San Marcos, TX 78666 \\ ${ }^{2}$ Department of Physics and Astronomy, The University of Texas at San Antonio, \\ One UTSA Circle. San Antonio, TX 78249
${ }^{*}$ Corresponding author: Tel.: 512.245.6721, Fax: 512.245.2374, e-mail address: cprhodes@txstate.edu Revised manuscript submitted to the Journal of Power Sources December 16, 2016 


\begin{abstract}
Rechargeable magnesium batteries provide the potential for lower cost and improved safety compared with lithium-ion batteries, however obtaining cathode materials with highly reversible Mg-ion capacities is hindered by the high polarizability of divalent Mg-ions and slow solid-state Mg-ion diffusion. We report that incorporating poly(ethylene oxide) (PEO) between the layers of hydrated vanadium pentoxide $\left(\mathrm{V}_{2} \mathrm{O}_{5}\right)$ xerogels results in significantly improved reversible $\mathrm{Mg}$-ion capacities. X-ray diffraction and high resolution transmission electron microscopy show that the interlayer spacing between $\mathrm{V}_{2} \mathrm{O}_{5}$ layers was increased by PEO incorporation. Vibrational spectroscopy supports that the polymer interacts with the $\mathrm{V}_{2} \mathrm{O}_{5}$ lattice. The $\mathrm{V}_{2} \mathrm{O}_{5}-\mathrm{PEO}$ nanocomposite exhibited a 5-fold enhancement in Mg-ion capacity, improved stability, and improved rate capabilities compared with $\mathrm{V}_{2} \mathrm{O}_{5}$ xerogels. The Mg-ion diffusion coefficient of the nanocomposite was increased compared with that of $\mathrm{V}_{2} \mathrm{O}_{5}$ xerogels and is attributed to enhanced Mg-ion mobility due to shielding interaction of PEO with the $\mathrm{V}_{2} \mathrm{O}_{5}$ lattice. This study shows that beyond only interlayer spacing, the nature of interlayer interactions of $\mathrm{Mg}$-ions with $\mathrm{V}_{2} \mathrm{O}_{5}, \mathrm{PEO}$, and $\mathrm{H}_{2} \mathrm{O}$ are key factors that affect $\mathrm{Mg}$-ion charge transport and storage in layered materials. The design of layered materials with controlled interlayer interactions provides a new approach to develop improved cathodes for magnesium batteries.
\end{abstract}

Key words: Magnesium batteries; cathodes; vanadium pentoxide; poly(ethylene oxide); nanocomposites; electrochemical energy storage 


\section{Introduction}

Electrochemical energy storage devices with low-cost, improved safety, high gravimetric specific energies, and high volumetric energy densities are needed for numerous applications including electric vehicles, consumer devices, and grid-level energy storage [1]. During the last two decades, lithium-ion (Li-ion) batteries have become widely utilized in mobile devices and electric vehicles due to their high specific energies and energy densities. Despite their successes, the high costs and significant safety issues of Li-ion batteries have resulted in research and development aimed at exploring alternative battery chemistries [2-4]. Electrical energy storage devices that are safe, utilize earth abundant elements, and provide high performance are of significant interest.

As an alternative to lithium-based systems, electrochemical energy storage systems based on the use of magnesium $(\mathrm{Mg})$ have attracted significant interest and attention [5-8]. Magnesium batteries have significant advantages compared to Li-ion batteries including improved safety resulting from dendrite-free $\mathrm{Mg}$ deposition, the use of environmentally-friendly and abundant materials (abundance in the earth's crust is $\sim 13.9 \% \mathrm{Mg}$ compared to $\sim 0.0007 \% \mathrm{Li})$, reduced cost $(\sim 2700 /$ ton for $\mathrm{Mg}$ compared to $\$ 64,000 /$ ton for $\mathrm{Li})$, high volumetric capacity $\left(3833 \mathrm{mAh} \mathrm{cm}^{-3}\right)$, and reasonable potential for $\mathrm{Mg}$ deposition (0.67 $\left.\mathrm{V} \mathrm{vs} \mathrm{Li}^{+} / \mathrm{Li}\right)$ [6, 8-10]. In 2000, Aurbach et. al. demonstrated the first prototype rechargeable $\mathrm{Mg}$ battery using a $\mathrm{Mo}_{6} \mathrm{~S}_{8}$ Chevrel phase cathode and a $\mathrm{Mg}$ metal anode, and the cell exhibited a reasonable energy density of $\sim 60 \mathrm{Wh} \mathrm{kg}^{-1}$ [8]. However, Chevrel phase cathodes have low voltages $\left(\sim 1.1 \mathrm{~V}\right.$ vs $\left.\mathrm{Mg} / \mathrm{Mg}^{2+}\right)$ and exhibit 
only partial reversibility, as the capacity drops by $\sim 40 \%$ after the first discharge cycle [11].

Obtaining cathodes that exhibit high capacities, high voltages, and excellent reversibility is a key challenge for the development of practical $\mathrm{Mg}$ batteries [12]. Subsequent to the demonstration of magnesium batteries using Chevrel phase $\mathrm{Mo}_{6} \mathrm{~S}_{8}$ cathodes, a number of cathode materials including metal oxides, metal chalcogenides, polyanionic structures, and spinel compounds have been investigated [7, 10, 13-18]. However, most of these cathodes materials suffer poor electrode kinetics and cycle performance due to low $\mathrm{Mg}^{2+}$ diffusion and structural instability [7]. Compared with a single valent $\mathrm{Li}^{+}$ion, a divalent $\mathrm{Mg}^{2+}$ ion has a high polarizability leading to strong interaction with the negatively charged host lattice $[19,20]$. The strong interaction of $\mathrm{Mg}^{2+}$ with the host lattice results in high energy barriers for intercalation and low Mg-ion diffusion coefficients [10]. Unlike $\mathrm{Li}^{+}$which can lose its solvation shell upon intercalation [21], $\mathrm{Mg}^{2+}$ intercalation has been shown to involve co-intercalation of solvent molecules [22].

In order to reduce strong host interactions and improve poor electrode kinetics several approaches have been introduced. One approach is to introduce molecules with strong dipole moments to solvate $\mathrm{Mg}^{2+}$ ions [23-25]. Song et.al. demonstrated the capability to significantly improve the Mg-ion insertion and deinsertion by introducing a small amount of $\mathrm{H}_{2} \mathrm{O}$ to the electrolyte, thereby decreasing $\mathrm{Mg}^{2+}$ polarization [23]. Trace $\mathrm{H}_{2} \mathrm{O}$ within the electrolyte can passivate $\mathrm{Mg}$ metal and adversely affect further $\mathrm{Mg}$ anode activity[24, 26], therefore the use of $\mathrm{H}_{2} \mathrm{O}$ within the electrolyte is not a viable approach for practical, rechargeable Mg batteries. Reducing particle dimensions to the nanoscale 
(i.e. nanostructuring) can increase ion diffusion by significantly decreasing the diffusion length [18]. However, downsizing the electrode material particle size to the nanoscale significantly decreases the volumetric energy density [10]. Additional approaches are needed to overcome the poor electrode kinetics of magnesium cathodes while avoiding issues that arise from introducing $\mathrm{H}_{2} \mathrm{O}$ into the electrolyte or nanostructuring.

Electrode materials with layered structures show significant potential as Mg-ion cathodes due to their ability to transport Mg-ions within the layers via different ion hopping mechanisms [27-30]. Among different types of layered metal oxides, vanadium pentoxide $\left(\mathrm{V}_{2} \mathrm{O}_{5}\right)$ has attracted a significant attention as a cathode material for $\mathrm{Mg}$ batteries $[13,26,31,32]$. Prior work has demonstrated that $\mathrm{V}_{2} \mathrm{O}_{5}$ can reversibly insert and de-insert Mg-ions [13, 26, 33]. Although large capacities have been reported for crystalline $\mathrm{V}_{2} \mathrm{O}_{5}$, the high capacities of crystalline $\mathrm{V}_{2} \mathrm{O}_{5}$ were shown to result from $\mathrm{H}_{2} \mathrm{O}$ within the electrolyte [26]. Crystalline $\mathrm{V}_{2} \mathrm{O}_{5}$ evaluated with an electrolyte with low $\mathrm{H}_{2} \mathrm{O}$ levels exhibited very low Mg-ion capacities ( 10-60 mAh g $\left.{ }^{-1}\right)$ [26].

$\mathrm{V}_{2} \mathrm{O}_{5}$ gels can be synthesized via sol-gel chemistry from both inorganic and metal-organic precursors [31, 34], and then dried under ambient conditions to form xerogels or supercritically dried to form aerogels. $\mathrm{V}_{2} \mathrm{O}_{5}$ xerogels (formula $\mathrm{V}_{2} \mathrm{O}_{5} \cdot \mathrm{nH}_{2} \mathrm{O}$ with $\mathrm{n}$ typically 1.6-2.0)[34] composed of $\mathrm{V}_{2} \mathrm{O}_{5}$ layers and structural interlayer $\mathrm{H}_{2} \mathrm{O}$ have shown to possess among the highest Mg-ion capacities and rate capabilities of $\mathrm{V}_{2} \mathrm{O}_{5}$ materials $[12,22,31]$. Recent characterization of the structural changes that occur during reversible Mg-ion insertion into hydrated $\mathrm{V}_{2} \mathrm{O}_{5}$ xerogels showed that $\mathrm{Mg}$-ions and solvent molecules co-intercalate between $\mathrm{V}_{2} \mathrm{O}_{5}$ layers which alters the interlayer spacing [22]. Monolithic hydrated $\mathrm{V}_{2} \mathrm{O}_{5}$ xerogels tested using a thin film electrode geometry that 
minimizes ion diffusion lengths exhibited high $\mathrm{Mg-ion}$ capacities of $150 \mathrm{mAh} \mathrm{g}^{-1}$ [13]; however, $\mathrm{V}_{2} \mathrm{O}_{5}$ xerogels tested within thicker electrode configurations using slurry-cast electrodes have been shown to exhibit Mg-ion capacities of $\sim 40 \mathrm{mAh} \mathrm{g}^{-1}$ [22]. The $\mathrm{H}_{2} \mathrm{O}$ within the $\mathrm{V}_{2} \mathrm{O}_{5}$ structure plays a critical role in solvating the $\mathrm{Mg}^{2+}$ ions, shielding the interaction of the divalent $\mathrm{Mg}$-ions with the $\mathrm{V}_{2} \mathrm{O}_{5}$ lattice, and facilitating insertion and deinsertion with the electrode structure as shown from calculations[35] and experiments [26]. The stability of structural interlayer $\mathrm{H}_{2} \mathrm{O}$ during $\mathrm{Mg}$-ion insertion/de-insertion within $\mathrm{V}_{2} \mathrm{O}_{5}$ varies between different studies [36, 37]. Le et. al. determined that structural interlayer water in hydrated $\mathrm{V}_{2} \mathrm{O}_{5}$ aerogels was retained upon cycling [37]. Novak et. al. reported that upon charging in hydrated $\mathrm{V}_{2} \mathrm{O}_{5}$ xerogel some $\mathrm{H}_{2} \mathrm{O}$ molecules remained bound to $\mathrm{Mg}$ and are removed from the $\mathrm{V}_{2} \mathrm{O}_{5}$ lattice [36]. The potential for removal of $\mathrm{H}_{2} \mathrm{O}$ from the structure upon cycling can ultimately lead to the structural failure and capacity fading [12]. Approaches that provide interlayers that (i) coordinate $\mathrm{Mg}^{2+}$, (ii) shield interaction with the negatively charged host lattice, and (iii) remain as stable interlayer scaffolds are of significant interest.

Nanocomposites of $\mathrm{V}_{2} \mathrm{O}_{5}$ with a number of polymers, including PEO [38], polyethylene glycol [39], poly(3,4-ethylenedioxythiophene) [40], polypyrrole [41], and polyaniline $[41,42]$ have been reported. The intercalation of PEO within the $\mathrm{V}_{2} \mathrm{O}_{5}$ xerogel layers was shown to increase the interlayer spacing and improve Li-ion intercalation [38]. Recently, Yao et. al. demonstrated that the physical mixing of PEO and exfoliated $\mathrm{MoS}_{2}$ could be used to increase the interlayer spacing of $\mathrm{MoS}_{2}$ improve the Mg-ion capacity of $\mathrm{MoS}_{2}[10]$. 
In this work, we report for the first time that the incorporation of PEO between the $\mathrm{V}_{2} \mathrm{O}_{5}$ layers can result in a significant improvement in $\mathrm{Mg}$-ion charge storage. In contrast to physical mixing of exfoliated layers and the polymer, the polymer was introduced during the $\mathrm{V}_{2} \mathrm{O}_{5}$ sol-gel synthesis to allow intimate mixing of the PEO and $\mathrm{V}_{2} \mathrm{O}_{5}$. The introduction of a polymer in the $\mathrm{V}_{2} \mathrm{O}_{5}$ interlayer was investigated as an approach to expand the interlayer spacing and reduce the interaction of divalent $\mathrm{Mg}^{2+}$ with the host $\mathrm{V}_{2} \mathrm{O}_{5}$ lattice. The expansion of the interlayer spacing resulting from the incorporation of the polymer was confirmed by TEM and x-ray diffraction analyses. The $\mathrm{V}_{2} \mathrm{O}_{5}$-PEO nanocomposites were determined to provide significantly higher Mg-ion capacities than the $\mathrm{V}_{2} \mathrm{O}_{5}$ xerogel. The $\mathrm{V}_{2} \mathrm{O}_{5}$-PEO nanocomposite showed an approximate $\sim 500 \%$ increase in capacity compared to pure $\mathrm{V}_{2} \mathrm{O}_{5}$ xerogels, which is a significant improvement achieved without the use of additional solvent molecules (i.e. $\mathrm{H}_{2} \mathrm{O}$ ) within the electrolyte, reducing particle size, or using a thin film geometry. Direct interaction of the polymer with the $\mathrm{V}_{2} \mathrm{O}_{5}$ lattice was supported by infrared and Raman spectroscopy. The polymer and interlayer water were determined to play important roles in facilitating Mg-ion diffusion and improving Mg-ion charge storage. The design of layered materials with controlled interlayer interactions and spacing provides a new approach to altering the interaction between $\mathrm{Mg}^{2+}$ ions and the host lattice thereby improving electrochemical Mg-ion charge storage.

\section{Experimental}

Chemicals and Materials: Sodium metavanadate $\left(\mathrm{NaVO}_{3}\right)$, Dowex 50WX2-100 cation-exchange resin, poly(ethylene oxide) (PEO, avg. MW 400,000), magnesium 
perchlorate, $\mathrm{Mg}\left(\mathrm{ClO}_{4}\right)_{2}$, and acetonitrile (anhydrous, 99.8\%) were obtained from SigmaAldrich (St. Louis, MO) and used as received. Carbon fiber cloth (Spectracarb TM 2225 Type 700) was obtained from Engineering Fibers Technology (Shelton, CT).

Synthesis of vanadium pentoxide xerogels $\left(\mathbf{V}_{\mathbf{2}} \mathbf{O}_{\mathbf{5}}\right): \mathrm{V}_{2} \mathrm{O}_{5}$ xerogels were prepared from ion-exchange of $\mathrm{NaVO}_{3}$ solutions by adapting previously reported methods [43]. To synthesize the $\mathrm{V}_{2} \mathrm{O}_{5}$ xerogels, $25 \mathrm{~mL}$ of a $1.0 \mathrm{M} \mathrm{NaVO}_{3}$ aqueous solution was eluted thorough an ion-exchange column containing $50 \mathrm{~g}$ of cationexchange resin (Dowex 50WX2-100) and $200 \mathrm{~mL}$ de-ionized water. The first lightcolored $20 \mathrm{~mL}$ elution was discarded, and then the next $30 \mathrm{~mL}$ of dark orange-colored elution was collected. The $30 \mathrm{~mL}$ of the total collected elution was separated into five 6 $\mathrm{mL}$ portions and then diluted to $7 \mathrm{~mL}$ by adding $1 \mathrm{~mL}$ of de-ionized (DI) water. The additional water was added to result in the same vanadic acid concentration as used for the PEO-containing samples, as discussed below. The vanadic acid suspensions were allowed to gel for 24 hours, after which a wet $\mathrm{V}_{2} \mathrm{O}_{5}$ gel (hydrogel) was obtained. Following the formation of the $\mathrm{V}_{2} \mathrm{O}_{5}$ hydrogel, the sample was then dried at $60{ }^{\circ} \mathrm{C}$ under ambient atmosphere for approximately 16 hours to form the $\mathrm{V}_{2} \mathrm{O}_{5}$ xerogel.

Synthesis of $\mathbf{V}_{2} \mathrm{O}_{5}$-PEO nanocomposites: The synthesis of the $\mathrm{V}_{2} \mathrm{O}_{5}$-PEO nanocomposites was performed using a procedure similar to that used for the synthesis of the $\mathrm{V}_{2} \mathrm{O}_{5}$ xerogels. $6 \mathrm{~mL}$ elutions of vanadic acid were collected as described above. Separately, an aqueous PEO solution (50 $\mathrm{mg} \mathrm{mL}^{-1}$ of PEO in DI water) was prepared. The $\mathrm{V}_{2} \mathrm{O}_{5}$-PEO nanocomposites were synthesized by adding either $0.25 \mathrm{~mL}$ or $1 \mathrm{~mL}$ of the $50 \mathrm{mg} \mathrm{mL}^{-1}$ PEO solution. In order to keep the total volume and thus the total vanadic acid concentration constant, $0.75 \mathrm{~mL}$ of DI water was added to the sample containing 
$0.25 \mathrm{~mL}$ of PEO solution. The vanadic acid-PEO solutions were allowed to gel for 24 hours and then dried at $60{ }^{\circ} \mathrm{C}$ under ambient atmosphere for approximately 16 hours. The dried nanocomposites were notated as $\mathrm{V}_{2} \mathrm{O}_{5}-\mathrm{PEO}-1$ and $\mathrm{V}_{2} \mathrm{O}_{5}-\mathrm{PEO}-2$, for the samples prepared using $0.25 \mathrm{~mL}$ or $1 \mathrm{~mL}$ of $\mathrm{PEO}$ solution respectively. The concentration of PEO by mass was determined to be $5.8 \mathrm{wt} \%$ PEO and $20.0 \mathrm{wt} \%$ PEO for $\mathrm{V}_{2} \mathrm{O}_{5}$-PEO-1 and $\mathrm{V}_{2} \mathrm{O}_{5}$-PEO-2, respectively.

Structural and thermal characterization. X-ray powder diffraction (XRD) patterns were obtained using a Bruker (Billerica, MA) D8 Advance Eco X-ray Powder Diffractometer with $\mathrm{Cu} \mathrm{K} \alpha$ radiation. Scans were recorded for $2 \theta$ values between 5 and $70^{\circ}$, using a step size of $0.02^{\circ}$ and integration of $10 \mathrm{~s}$ per step. Scanning electron microscopy (SEM) images were obtained using a Helios NanoLab 400 DualBeam Field Emission Scanning Electron Microscope. Transmission electron microscopy (TEM) images were obtained using a JEOL JEM 1200EXII microscope. High resolution TEM (HRTEM) images were obtained a JEOL 2010F operated at $200 \mathrm{kV}$. TEM samples were prepared on lacey carbon grids by depositing a solution of the dried powder suspended in isopropanol. Samples were degassed at $120{ }^{\circ} \mathrm{C}$ for $16 \mathrm{~h}$ prior to characterization.

Thermogravimetric analysis (TGA, TA instruments Q50) was performed a constant heating rate of $10^{\circ} \mathrm{C} /$ min using air. Prior to TGA analysis, the $\mathrm{V}_{2} \mathrm{O}_{5}$ xerogel and $\mathrm{V}_{2} \mathrm{O}_{5}$-PEO nanocomposites were heated under vacuum at $120{ }^{\circ} \mathrm{C}$ for $16 \mathrm{~h}$. For the $\mathrm{V}_{2} \mathrm{O}_{5}$ xerogel, the sample was determined to have 1.8 moles $\mathrm{H}_{2} \mathrm{O}$ per mole of $\mathrm{V}_{2} \mathrm{O}_{5}$, notated as $\mathrm{V}_{2} \mathrm{O}_{5} \cdot 1.8 \mathrm{H}_{2} \mathrm{O}$, from the TGA mass loss up to $500{ }^{\circ} \mathrm{C}$ (Figure S1) consistent with previous reports $[34,44,45]$. Since the onset of PEO decomposition occurs above $\sim 200{ }^{\circ} \mathrm{C}$, mass loss above $200{ }^{\circ} \mathrm{C}$ results from both PEO decomposition [38] and removal of structural 
$\mathrm{H}_{2} \mathrm{O}$. To avoid the PEO decomposition region, the hydration levels for the $\mathrm{V}_{2} \mathrm{O}_{5}-\mathrm{PEO}$ nanocomposites were determined at $200{ }^{\circ} \mathrm{C}$ and compared with the hydration level of the $\mathrm{V}_{2} \mathrm{O}_{5}$ xerogel at $200{ }^{\circ} \mathrm{C}$ to allow for comparison. At $200{ }^{\circ} \mathrm{C}$, the composition of the xerogel was determined to be $\mathrm{V}_{2} \mathrm{O}_{5} \cdot 1.5 \mathrm{H}_{2} \mathrm{O}$, which indicates 0.3 moles of $\mathrm{H}_{2} \mathrm{O}$ are removed from the structure above $200^{\circ} \mathrm{C}$.

Infrared spectra of the $\mathrm{V}_{2} \mathrm{O}_{5}$ xerogel, $\mathrm{V}_{2} \mathrm{O}_{5}$-PEO nanocomposites, and pure PEO were collected over the range of $4700-4000 \mathrm{~cm}^{-1}$ using a Harrick Scientific (Pleasantville, NY) SplitPea attenuated total (internal) reflectance (ATR) microsampling accessory coupled to a Bruker (Billerica, MA) Tensor II FT-IR spectrometer that utilized a wideband, liquid-nitrogen cooled mercury-cadmium-telluride (MCT) detector. The ATR accessory featured a silicon hemispherical internal reflection element (IRE), and the samples were brought into direct, optical contact with the IRE using a loading of $0.5 \mathrm{~kg}$. The collected spectra represent the average of 64 individual scans collected at a spectral resolution of $4 \mathrm{~cm}^{-1}$. Instrument control of the Tensor II FT-IR spectrometer and analysis of the resulting spectra were done using Bruker OPUS 7.5 software (version 7.5.18).

Raman spectra were obtained with a Horiba LabRam HR Evolution Confocal Raman Spectrometer equipped with an 1800 groove/mm grating. Sample excitation was performed using the $514 \mathrm{~nm}$ line of a Melles Griot (Carlsbad, CA) argon-ion laser. Raman scattered light was collected in a backscattering geometry using an Olympus (Center Valley, PA) 50× (0.75 NA) MPlan N objective. Spectra were obtained using a 25 second acquisition time and averaged over 10-20 accumulations. Laser-induced thermal effects were observed in prior Raman studies of vanadium pentoxide [46], and low laser powers are necessary to minimize spectral changes due to local heating. In order to avoid 
sample degradation, the laser power was controlled below $0.30 \mathrm{~mW}$ using neutral density filters. Visual inspection of the samples, pre- and post-analysis, using white light illumination did not reveal any laser-induced changes. To further verify that the laser did not induce spectral changes, spectra were obtained at a laser power of below $0.03 \mathrm{~mW}$ using the same acquisition and sampling conditions as above; no differences were observed compared to the spectra taken at $0.3 \mathrm{~mW}$.

Electrochemical testing. Electrodes were fabricated from a slurry composed of $80 \mathrm{wt} \%$ active material (typically $\sim 150-200 \mathrm{mg}$ of sample), $10 \mathrm{wt} \%$ conductive carbon (TIMCAL Super C65), and $10 \mathrm{wt} \%$ binder (Arkema, Kynar HSV900 - 5\% in N-Methyl2-pyrrolidinone (NMP)) using a similar method previously reported [47]. Excess NMP was added to control the viscosity of the slurry. The slurry was stirred overnight and then cast using a doctor blade (gap setting of $200 \mu \mathrm{m}$ ) on a cleaned $15 \mu \mathrm{m}$-thick aluminum foil current collector. The obtained electrode sheet was dried overnight in a fume hood and then transferred into an oven at $60^{\circ} \mathrm{C}$ and allowed to dry overnight to remove excess solvent. Electrodes were cut and then further dried at $120{ }^{\circ} \mathrm{C}$ under vacuum overnight. The average mass loading was $2.4 \mathrm{mg} / \mathrm{cm}^{2}$. The electrolyte, $1 \mathrm{M} \mathrm{Mg}\left(\mathrm{ClO}_{4}\right)_{2}$ in acetonitrile $\left(\mathrm{CH}_{3} \mathrm{CN}\right)$, was prepared by combining $\mathrm{Mg}\left(\mathrm{ClO}_{4}\right)_{2}$ (dried at $120^{\circ} \mathrm{C}$ under vacuum for at least 16 hours prior to use) and dried acetonitrile within an inert atmosphere glovebox (Argon, $\leq 1 \mathrm{ppm} \mathrm{H}_{2} \mathrm{O}$ ). The dried acetonitrile was prepared by distillation and degassing and then stored over $4 \AA$ (8-12 mesh beads) dried molecular sieves within the glovebox. Electrochemical analysis was performed using standard three electrode cell configuration using $1 \mathrm{M} \mathrm{Mg}\left(\mathrm{ClO}_{4}\right)_{2}$ in acetonitrile as the electrolyte and magnesium foil as the reference electrode. A Spectrocarb carbon cloth was used as the 
counter electrode since previous studies evaluating magnesium deposition and stripping have shown that significant solvent reduction rather than magnesium plating occurs within electrolytes composed of magnesium salts in acetonitrile [48, 49]. Prior to use, the magnesium foil was roughened with sandpaper and thoroughly wiped using Kimwipes (Kimberly Clark, Irving, Texas). All electrochemical cell fabrication and testing was performed in an inert atmosphere glovebox (Argon, $\leq 1 \mathrm{ppm} \mathrm{H}_{2} \mathrm{O}$ ). For comparison, electrodes were tested using an $\mathrm{Ag} / \mathrm{AgCl}$ reference electrode, and similar electrochemical results were obtained. Galvanostatic charge-discharge were collected over a voltage range of 1.0 to $3.0 \mathrm{~V}$ vs $\mathrm{Mg} / \mathrm{Mg}^{2+}$ with a mass-normalized current of $10 \mathrm{~mA} \mathrm{~g}^{-1}$ active material using an Arbin Instruments (College Station, TX) BT2043 test station. Cyclic voltammograms were determined using the same configuration over a voltage range of 1.0 to $3.0 \mathrm{~V}$ vs $\mathrm{Mg} / \mathrm{Mg}^{2+}$ at scan rates of 2.5 to $7.5 \mathrm{mV} / \mathrm{s}$. Coulombic efficiencies were determined from the average of the last 5 cycles of the cycling tests.

To evaluate whether PEO was maintained in the $\mathrm{V}_{2} \mathrm{O}_{5}$-PEO nanocomposite films after cycling within the electrolyte $\left(1 \mathrm{M} \mathrm{Mg}\left(\mathrm{ClO}_{4}\right)_{2}\right.$ in $\left.\mathrm{CH}_{3} \mathrm{CN}\right)$, FTIR-ATR spectra of $\mathrm{V}_{2} \mathrm{O}_{5}$-PEO- 1 and $\mathrm{V}_{2} \mathrm{O}_{5}$-PEO-2 cast electrode films were obtained before and after cycling using the instrumental setup described above. The FTIR-ATR spectra were obtained using the same parameters expect 128 scans rather than 64 scans were used for the spectral acquisition. The $\mathrm{V}_{2} \mathrm{O}_{5}$-PEO-1 and $\mathrm{V}_{2} \mathrm{O}_{5}$-PEO-2 electrodes were cycled five times in the electrolyte at a scan rate of $2.5 \mathrm{mV} \mathrm{s}-1$ over a voltage range of 1.0 to $3.0 \mathrm{~V}$ vs $\mathrm{Mg}$. After cycling and prior to collecting FTIR-ATR spectra, the electrodes were rinsed three times with distilled acetonitrile ( $5 \mathrm{~mL}$ portions), allowed to dry inside the glovebox, and then placed inside the vacuum chamber of the glovebox for $2 \mathrm{hrs}$. 


\section{Results and Discussion}

\subsection{Approach for altering the interlayer spacing of $\mathrm{V}_{2} \mathrm{O}_{5}$ gels}

The incorporation of a polymer between the $\mathrm{V}_{2} \mathrm{O}_{5}$ layers was investigated to increase the interlayer spacing between the $\mathrm{V}_{2} \mathrm{O}_{5}$ layers and decrease the interaction of highly polarized $\mathrm{Mg}^{2+}$ ions with the negatively charged $\mathrm{V}_{2} \mathrm{O}_{5}$ layer. To incorporate a polymer within the $\mathrm{V}_{2} \mathrm{O}_{5}$ layers, we introduced poly(ethylene oxide), PEO, during the growth of the $\mathrm{V}_{2} \mathrm{O}_{5}$ gels (represented graphically in Figure 1a,b). $\mathrm{V}_{2} \mathrm{O}_{5} \cdot \mathrm{nH}_{2} \mathrm{O}$ nanosheets are formed from aqueous vanadic acid solutions [34]. At low $\mathrm{pH}$, aqueous vanadic acid species such as tetrahedrally coordinated $\mathrm{VO}(\mathrm{OH})_{3}$ species are generated [34]. The $\mathrm{VO}(\mathrm{OH})_{3}$ species become 6-fold coordinate with water addition and combine via condensation reactions to form polyanions composed of edge or corner-sharing $\left[\mathrm{VO}_{4}\right]^{3-}$ tetrahedral that further grow into extended $\mathrm{V}_{2} \mathrm{O}_{5} \cdot \mathrm{nH}_{2} \mathrm{O}$ sheets that form an interconnected network [34]. 
(a)
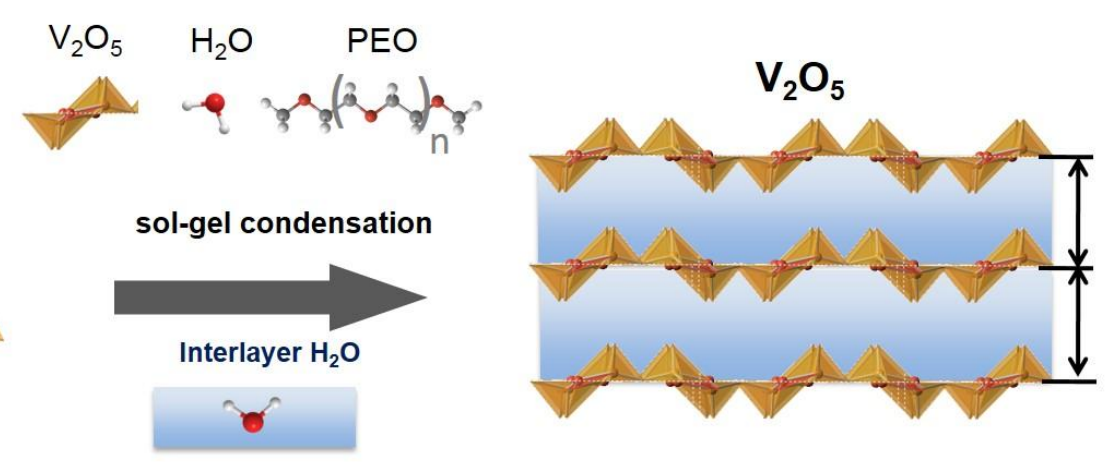

(b)
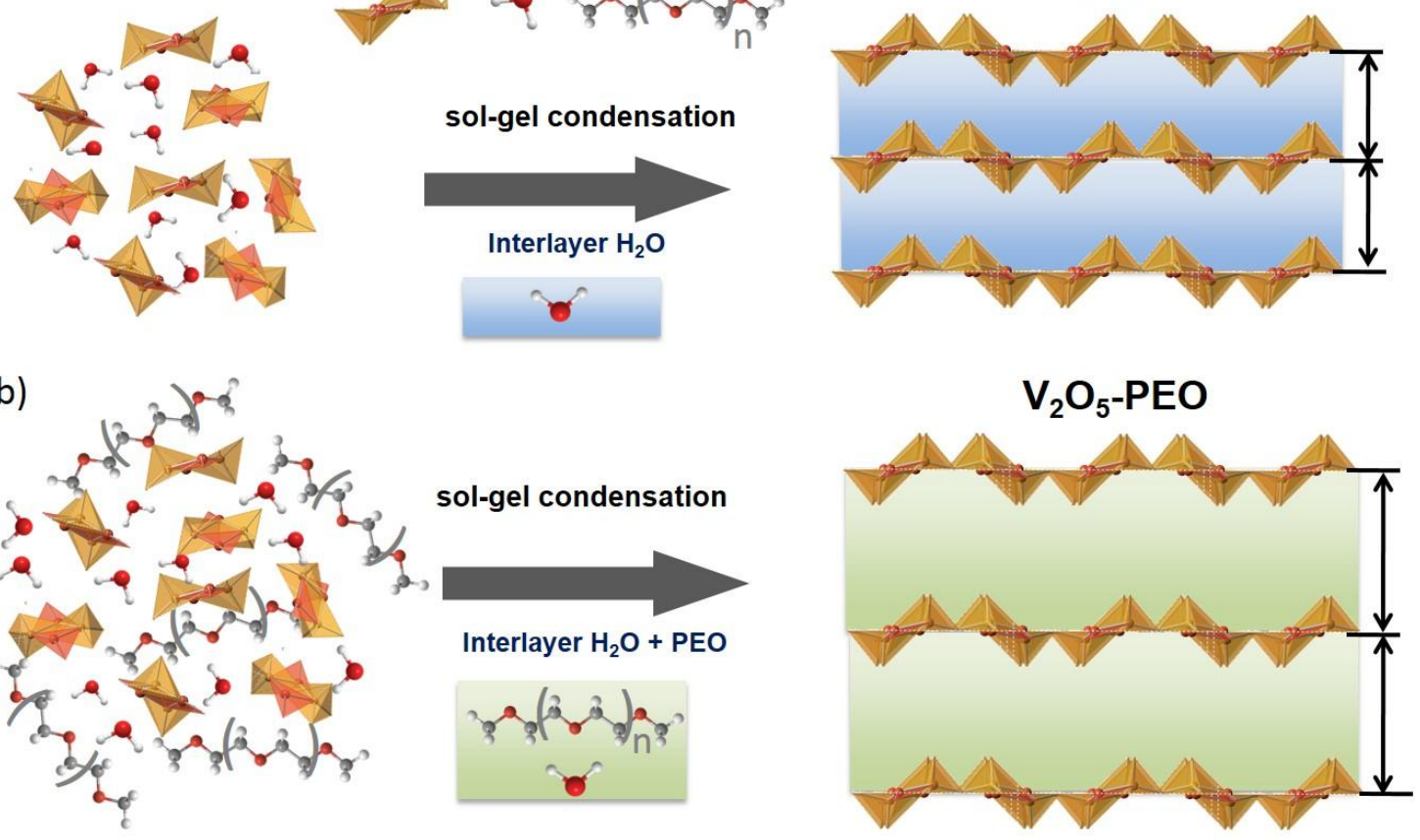

Figure 1. Graphical representation of growth of hydrated $\mathrm{V}_{2} \mathrm{O}_{5}$ nanosheet formation from water addition and condensation reactions of $\left[\mathrm{VO}_{4}\right]^{3-}$ polyanions in aqueous solution at low pH; (a) without poly(ethylene oxide) (PEO); (b) with PEO.

A representation of the process of incorporating PEO between the $\mathrm{V}_{2} \mathrm{O}_{5}$ nanosheets is shown in Figure 1b. Instead of exfoliating the nanosheets and adding PEO, the polymer was added directly to the vanadic acid solution. The $\mathrm{V}_{2} \mathrm{O}_{5}$ nanosheets were grown in the presence of PEO, thereby allowing the incorporation of PEO and $\mathrm{H}_{2} \mathrm{O}$ between the $\mathrm{V}_{2} \mathrm{O}_{5}$ layers (Figure 1b). Prior work has shown that the ether oxygens of PEO strongly interact with vanadic acid species and $\mathrm{V}_{2} \mathrm{O}_{5}$ [34]. Using this in-situ approach facilitated the interaction of PEO with the $\mathrm{V}_{2} \mathrm{O}_{5}$ lattice. In order to determine the effect of polymer composition on the interlayer spacing and electrochemical properties, different amounts of PEO were introduced into the solution. The PEO- 
containing materials are notated as $\mathrm{V}_{2} \mathrm{O}_{5}$-PEO- 1 and $\mathrm{V}_{2} \mathrm{O}_{5}-\mathrm{PEO}-2$ and are compared with the $\mathrm{V}_{2} \mathrm{O}_{5}$ xerogel without PEO.

All samples formed hydrated gels, which were dried as described in the experimental section to form xerogels. The dried $\mathrm{V}_{2} \mathrm{O}_{5}$ xerogel and $\mathrm{V}_{2} \mathrm{O}_{5}$-PEO nanocomposites are hydrates and can be represented as $\mathrm{V}_{2} \mathrm{O}_{5} \cdot \mathrm{nH}_{2} \mathrm{O}$. TGA analysis (Figure $\mathrm{S} 1$ ) showed that for the $\mathrm{V}_{2} \mathrm{O}_{5}$ xerogel, $\mathrm{n}=1.8$ based on the loss in sample mass up to $500^{\circ} \mathrm{C}$, and we note that the measured hydration level is identical to similarly prepared xerogels [44]. Determining the degree of hydration for the $\mathrm{V}_{2} \mathrm{O}_{5}-\mathrm{PEO}$ nanocomposites from TGA was more complicated due to decomposition of $\mathrm{PEO}$, however the $\mathrm{V}_{2} \mathrm{O}_{5}$-PEO nanocomposites and $\mathrm{V}_{2} \mathrm{O}_{5}$ xerogel showed a similar mass loss up to $200{ }^{\circ} \mathrm{C}$ (Figure $\mathrm{S} 1$ ), suggesting that the degree of hydration was similar between the samples. Based on the mass of PEO within the samples and $\mathrm{H}_{2} \mathrm{O}$ evaluated at $200{ }^{\circ} \mathrm{C}$ from TGA, the molar ratios of $\mathrm{V}_{2} \mathrm{O}_{5}$, PEO and $\mathrm{H}_{2} \mathrm{O}$ were represented by the formula $\left(\mathrm{V}_{2} \mathrm{O}_{5}\right)_{\mathrm{x}}\left(-\mathrm{OCH}_{2} \mathrm{CH}_{2}-\right.$ )$_{\mathrm{y}} \cdot \mathrm{nH}_{2} \mathrm{O}$ and were determined to be $\mathrm{V}_{2} \mathrm{O}_{5} \cdot 1.5 \mathrm{H}_{2} \mathrm{O},\left(\mathrm{V}_{2} \mathrm{O}_{5}\right)\left(-\mathrm{OCH}_{2} \mathrm{CH}_{2}-\right)_{0.3} \cdot 1.5 \mathrm{H}_{2} \mathrm{O}$, and $\left(\mathrm{V}_{2} \mathrm{O}_{5}\right)\left(-\mathrm{OCH}_{2} \mathrm{CH}_{2-}\right)_{1.2} \cdot 2.0 \mathrm{H}_{2} \mathrm{O}$ for the $\mathrm{V}_{2} \mathrm{O}_{5}$ xerogel, $\mathrm{V}_{2} \mathrm{O}_{5}-\mathrm{PEO}-1$ and $\mathrm{V}_{2} \mathrm{O}_{5}-\mathrm{PEO}-2$ samples respectively.

\subsection{Scanning and transmission electron microscopy of $\mathrm{V}_{2} \mathrm{O}_{5}$ xerogels and $\mathrm{V}_{2} \mathrm{O}_{5}-\mathrm{PEO}$ nanocomposites}

The morphologies of the $\mathrm{V}_{2} \mathrm{O}_{5}$ and $\mathrm{V}_{2} \mathrm{O}_{5}$-PEO samples were examined using SEM TEM, and HRTEM (Figure 2a-c). From the SEM images, nanosheets with crumpled morphologies were observed for the $\mathrm{V}_{2} \mathrm{O}_{5}$ xerogels and $\mathrm{V}_{2} \mathrm{O}_{5}$ - $\mathrm{PEO}$ nanocomposites. Both nanocomposites with $\mathrm{PEO}, \mathrm{V}_{2} \mathrm{O}_{5}$-PEO-1 and $\mathrm{V}_{2} \mathrm{O}_{5}$-PEO-2, exhibited similar 
nanosheet structures as the $\mathrm{V}_{2} \mathrm{O}_{5}$ xerogel indicating that the inclusion of PEO during the $\mathrm{V}_{2} \mathrm{O}_{5}$ synthesis did not significantly alter the formation of $\mathrm{V}_{2} \mathrm{O}_{5}$ nanosheets. The lateral size of the $\mathrm{V}_{2} \mathrm{O}_{5}$ nanosheet was determined to be $\sim 2-3 \mu \mathrm{m}$. The nanosheet structure is further shown by the TEM images of $\mathrm{V}_{2} \mathrm{O}_{5}, \mathrm{~V}_{2} \mathrm{O}_{5}$-PEO-1 and $\mathrm{V}_{2} \mathrm{O}_{5}-\mathrm{PEO}-2$ (Figure 2d-f). Based on analysis of the TEM images, the growth process results in several stacked nanosheet layers.

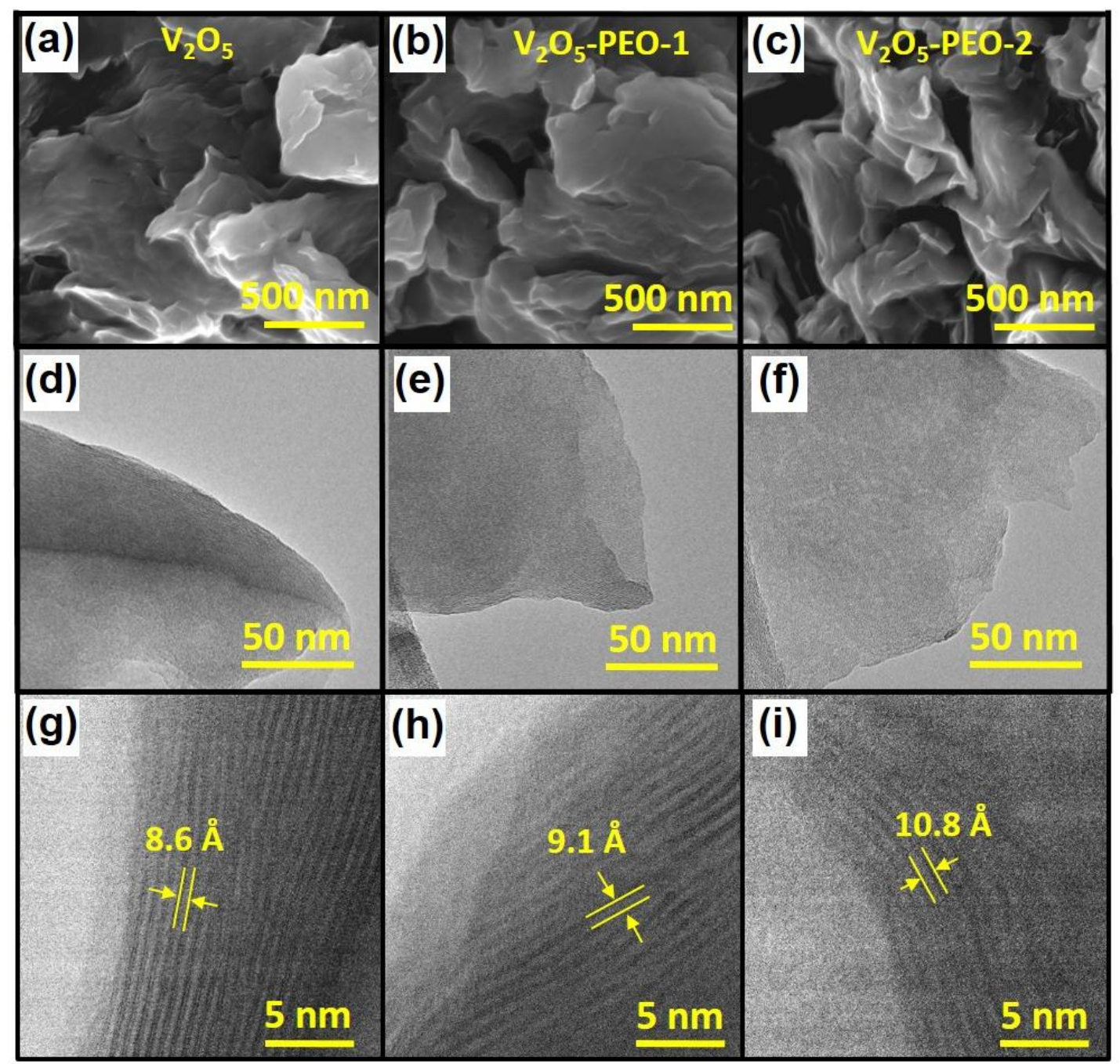

Figure 2. Scanning electron microscopy (SEM) images of $\mathrm{V}_{2} \mathrm{O}_{5}$ xerogel (a), $\mathrm{V}_{2} \mathrm{O}_{5}$-PEO-1 (b), and $\mathrm{V}_{2} \mathrm{O}_{5}$-PEO-2 nanocomposite (c); Transmission electron microscopy (TEM) images of $\mathrm{V}_{2} \mathrm{O}_{5}$ xerogel (d), $\mathrm{V}_{2} \mathrm{O}_{5}$-PEO-1 (e), and $\mathrm{V}_{2} \mathrm{O}_{5}$-PEO-2 nanocomposite (f); Highresolution TEM images showing $d$-spacings of $\mathrm{V}_{2} \mathrm{O}_{5}$ xerogel $(\mathrm{g}), \mathrm{V}_{2} \mathrm{O}_{5}$-PEO-1 (h), and $\mathrm{V}_{2} \mathrm{O}_{5}$-PEO-2 nanocomposite (i). 
A determination of the interlayer spacing ( $d$-spacing) between the nanosheets was performed using the HRTEM images of the $\mathrm{V}_{2} \mathrm{O}_{5}$ xerogel and $\mathrm{V}_{2} \mathrm{O}_{5}$-PEO nanocomposites (Fig. 2g-i). The high resolution TEM images show $d$-spacings of $\sim 8.6$, 9.1, and $10.8 \AA$ for the $\mathrm{V}_{2} \mathrm{O}_{5}$ xerogel, $\mathrm{V}_{2} \mathrm{O}_{5}$-PEO-1 nanocomposite, and $\mathrm{V}_{2} \mathrm{O}_{5}$-PEO-2 nanocomposite respectively. The measured interlayer spacings are in the range of previously reported values [34, 38]. The interlayer spacing was increased with the incorporation of PEO within the structure, and higher amounts of PEO were observed to result in larger $d$-spacings.

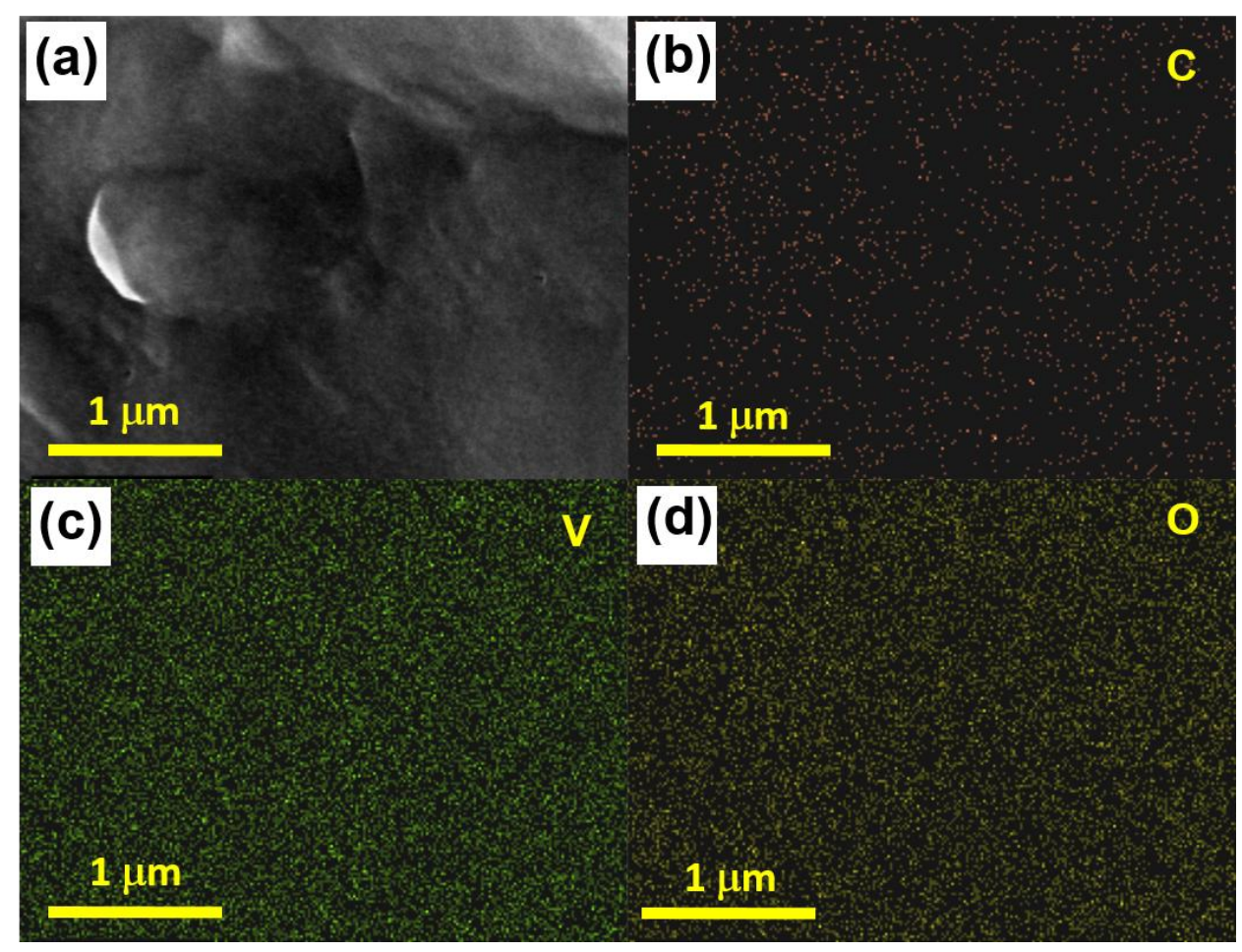

Figure 3. Energy dispersive spectroscopy (EDS) elemental mapping of $\mathrm{V}_{2} \mathrm{O}_{5}-\mathrm{PEO}-1$ nanocomposite; (a) SEM image; corresponding EDS mappings of (b) carbon (C), (c) vanadium $(\mathrm{V})$, and $(\mathrm{d})$ oxygen $(\mathrm{O})$ elements of $\mathrm{V}_{2} \mathrm{O}_{5}-\mathrm{PEO}-1$. 
Energy dispersive spectroscopy (EDS) element mapping was used to evaluate the distribution of PEO within the nanocomposites. The SEM image and EDS mapping of the $\mathrm{V}_{2} \mathrm{O}_{5}-\mathrm{PEO}-1$ sample are shown in Figure 3. From the EDS analysis, carbon, vanadium, and oxygen are evenly distributed within the nanocomposite supporting that PEO is uniformly distributed within the $\mathrm{V}_{2} \mathrm{O}_{5}$ layers rather than forming a separate, distinct phase. We also observed a uniform distribution of PEO for $\mathrm{V}_{2} \mathrm{O}_{5}-\mathrm{PEO}-2$ that has the highest content of PEO (Figure S2). The uniform distribution of PEO within the $\mathrm{V}_{2} \mathrm{O}_{5}$ layers for both composition indicates the feasibility to obtain controlled PEO contents with uniform distributions during the growth of $\mathrm{V}_{2} \mathrm{O}_{5}$ nanosheets.

\subsection{X-ray diffraction characterization of $\mathrm{V}_{2} \mathrm{O}_{5}$ xerogels and $\mathrm{V}_{2} \mathrm{O}_{5}$-PEO nanocomposites}

X-ray diffraction (XRD) was used to characterize long-range order within the $\mathrm{V}_{2} \mathrm{O}_{5}$ xerogels and $\mathrm{V}_{2} \mathrm{O}_{5}$-PEO nanocomposites. The X-ray diffraction (XRD) powder patterns for the $\mathrm{V}_{2} \mathrm{O}_{5}$ xerogel and $\mathrm{V}_{2} \mathrm{O}_{5}$-PEO- 1 and $\mathrm{V}_{2} \mathrm{O}_{5}$-PEO-2 nanocomposites are shown in Figure 4a. The relatively broad peak widths and high signal-to-noise ratios are a result of the low degree of crystallinity within the materials.

The XRD peak positions of the $\mathrm{V}_{2} \mathrm{O}_{5}$ xerogel are similar to those reported in earlier studies [50-52], and can be indexed to the $\mathrm{V}_{2} \mathrm{O}_{5} \cdot \mathrm{nH}_{2} \mathrm{O}$ phase (JCPDS\#:01-0743093) with a monoclinic unit cell under space group $\mathrm{C} / 2 \mathrm{~m}(\mathrm{a}=11.722 \AA, \mathrm{b}=3.570 \AA$, $\mathrm{c}=11.520 \AA, \beta=88.65^{\circ}$ ) [53]. The observation of multiple $00 \ell$ reflections is consistent with the layered structure of hydrated $\mathrm{V}_{2} \mathrm{O}_{5}$ [54]. The absence of a (002) peak has been explained by a bilayer structure [55]. The $2 \theta^{\circ}$ value of the highest intensity peak (001), 
corresponds to a basal ( $d$-spacing) of $11.6 \AA$ and is consistent with intercalation of a single $\mathrm{H}_{2} \mathrm{O}$ layer [52]. In addition to $00 \ell$ reflections, the position of peak at $2 \theta^{\circ}=25.4$ is closest to $2 \theta^{\circ}$ value of (110) planes and was previously identified as arising from inplane $(h k l)$ reflections [34].
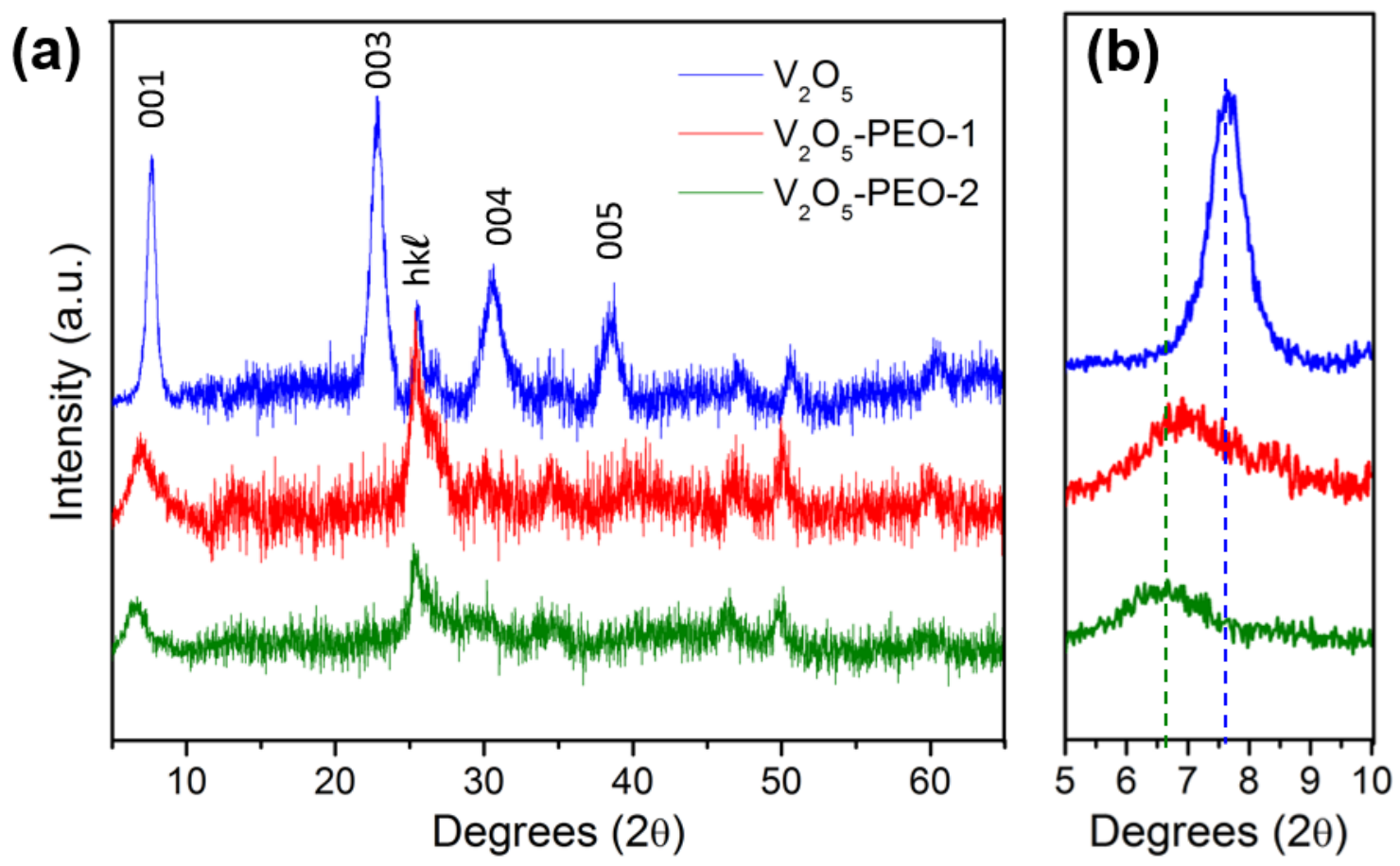

Figure 4. (a) X-Ray diffraction (XRD) powder patterns of $\mathrm{V}_{2} \mathrm{O}_{5}$ xerogel, $\mathrm{V}_{2} \mathrm{O}_{5}-\mathrm{PEO}-1$, and $\mathrm{V}_{2} \mathrm{O}_{5}$-PEO-2 nanocomposite; (b) Expanded region from $2 \theta^{\circ}=\sim 5-10$ showing shifting of the (001) peak to lower $2 \theta^{\circ}$ values upon introduction of PEO.

For the XRD patterns of the $\mathrm{V}_{2} \mathrm{O}_{5}$-PEO-2 nanocomposites, the in-plane ( $\left.h k l\right)$ reflections remained, however clear differences were observed in the peaks due to the $00 \ell$ reflections. The (001) peak was observed for the $\mathrm{V}_{2} \mathrm{O}_{5}$ - $\mathrm{PEO}$ nanocomposites, however the (003) and (004) reflections were not observed, indicating a lower degree of longrange order between the $\mathrm{V}_{2} \mathrm{O}_{5}$ layers occurred upon incorporation of PEO. The polymer may induce disordered stacking between multiple layers [38]. The XRD patterns of the 
$\mathrm{V}_{2} \mathrm{O}_{5}$-PEO nanocomposites show similar diffraction peaks to those previously reported for PEO- intercalated $\mathrm{V}_{2} \mathrm{O}_{5}$ [38] and polyaniline-intercalated $\mathrm{V}_{2} \mathrm{O}_{5}[56]$.

For the $\mathrm{V}_{2} \mathrm{O}_{5}$-PEO nanocomposites, the positions of the (001) peaks shift towards lower angles relative to the position of the (001) peak for the $\mathrm{V}_{2} \mathrm{O}_{5}$ xerogel (Figure 4b), which indicates an increase in the interlayer spacing between the nanosheets by incorporation of PEO within the structure. The interlayer distance ( $d$-spacing) was calculated according to Bragg's law

$$
\mathrm{d}=\frac{\mathrm{n} \lambda}{2 \sin \theta}
$$

where $n$ is an integer, $\lambda$ is the X-ray wavelength (1.54 $\AA$ ), and $\theta$ is the angle between the incident rays and the sample. The d-spacing increased from $11.6 \AA$ for the $\mathrm{V}_{2} \mathrm{O}_{5}$ xerogel to 12.6 and $13.6 \AA$ for $\mathrm{V}_{2} \mathrm{O}_{5}$-PEO-1 and $\mathrm{V}_{2} \mathrm{O}_{5}$-PEO-2 nanocomposites, respectively. In addition, the width of the (001) peak increased for the PEO-containing samples, which is indicative of less ordered layers. The gradual increase of $d$-spacing for the $\mathrm{V}_{2} \mathrm{O}_{5}-\mathrm{PEO}$ nanocomposites suggests that the interlayer spacing can be controlled by increasing the amount of PEO added during the synthesis. The correlation between the increased $d$ spacing and the increased PEO content observed from the XRD data is consistent with the results obtained using HRTEM. Previously reported calculations support that PEO chains can be arranged within $\mathrm{V}_{2} \mathrm{O}_{5}$ layers in either helical or zigzag conformations [57]. The PEO chains were found to possess a helical conformation at low polymer contents and zigzag conformations when the polymer content was high. The calculated results of this earlier study did not take into account the solvent, which may alter the polymer conformations from these idealized geometries. 


\subsection{Infrared spectroscopic analysis of $\mathrm{V}_{2} \mathrm{O}_{5}$ xerogels and $\mathrm{V}_{2} \mathrm{O}_{5}$-PEO nanocomposites}

Vibrational spectroscopy was used to characterize the structure of the $\mathrm{V}_{2} \mathrm{O}_{5}$ xerogels and $\mathrm{V}_{2} \mathrm{O}_{5}$ - $\mathrm{PEO}$ nanocomposites and particularly investigate the nature of $\mathrm{V}_{2} \mathrm{O}_{5}$, PEO, and $\mathrm{H}_{2} \mathrm{O}$ within the nanocomposite. The ATR-FTIR spectra of $\mathrm{V}_{2} \mathrm{O}_{5}$ xerogels, $\mathrm{V}_{2} \mathrm{O}_{5}$-PEO nanocomposites, and pure PEO for comparison are shown in Figure 5. The FTIR spectra of the $\mathrm{V}_{2} \mathrm{O}_{5}$-PEO nanocomposites exhibited bands due to $\mathrm{V}_{2} \mathrm{O}_{5}$, PEO, and $\mathrm{H}_{2} \mathrm{O}$.
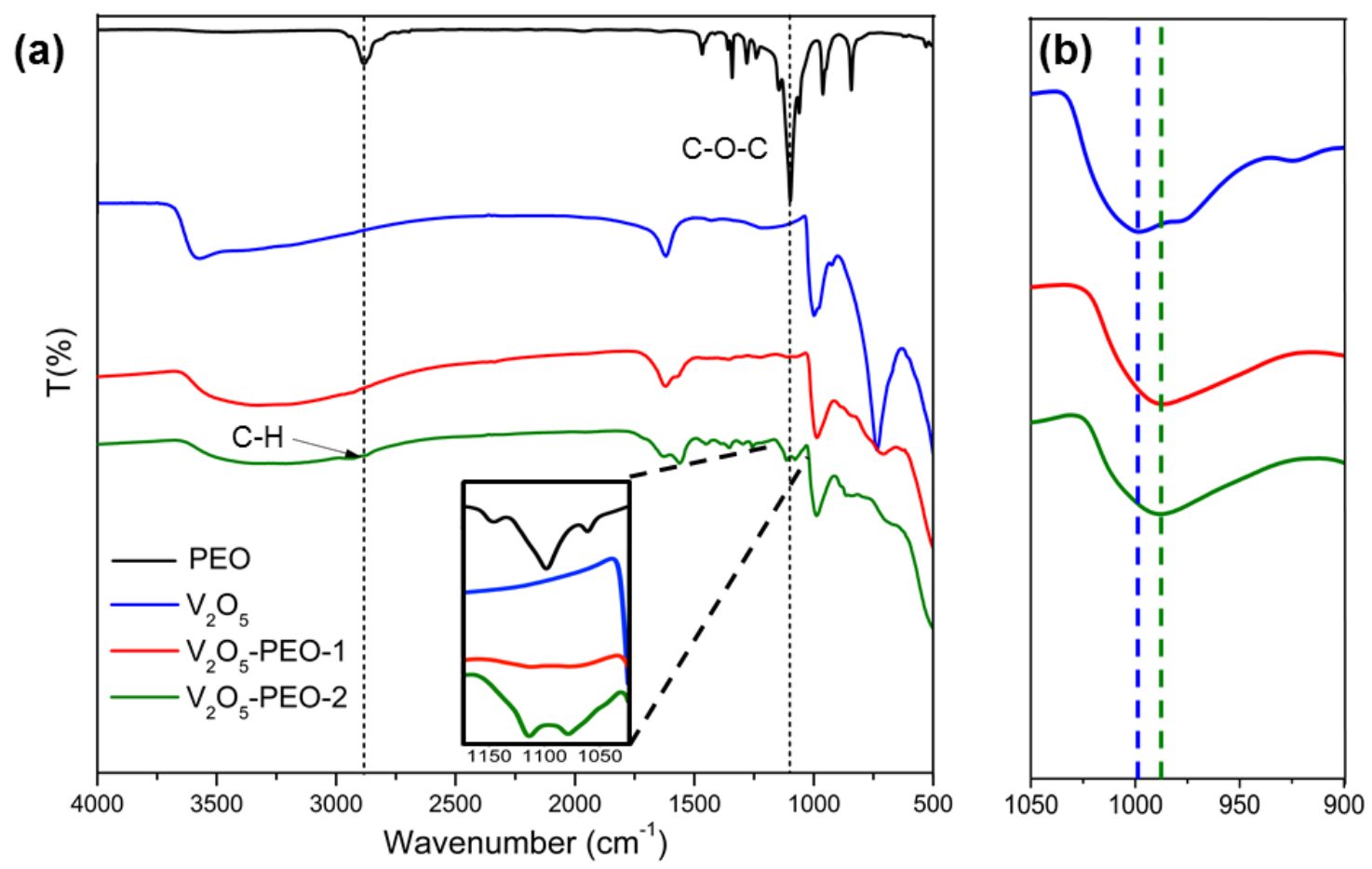

Figure 5. a) ATR-FTIR spectra of $\mathrm{V}_{2} \mathrm{O}_{5}$ xerogel, $\mathrm{V}_{2} \mathrm{O}_{5}$-PEO nanocomposites, and PEO; Bands corresponding to $\mathrm{C}-\mathrm{O}-\mathrm{C}, \mathrm{C}-\mathrm{H}$ and $\mathrm{v}_{\mathrm{S}}\left(\mathrm{V}=\mathrm{O}_{\mathrm{A}}\right)$ stretches are labeled; inset figure shows the expanded region from $\sim 1020-1170 \mathrm{~cm}^{-1}$ corresponding to the C-O-C stretching bands; (b) Expanded region from $800-1100 \mathrm{~cm}^{-1}$ showing the $v_{\mathrm{s}}(\mathrm{V}=\mathrm{O})$ downshift.

Infrared spectra and vibrational mode assignments of $\mathrm{V}_{2} \mathrm{O}_{5}$ xerogels at various levels of hydration have been previously reported [45]. The ATR-FTIR spectra of the $\mathrm{V}_{2} \mathrm{O}_{5}$ xerogel showed a band centered at $998 \mathrm{~cm}^{-1}$ which is attributed to a symmetric 
$v_{\mathrm{s}}\left(\mathrm{V}=\mathrm{O}_{\mathrm{A}}\right)$ stretching mode, and band at $800 \mathrm{~cm}^{-1}$ which has been assigned to the asymmetric $\mathrm{V}-\mathrm{O}-\mathrm{V}$ stretching mode of bridging oxygens, $\mathrm{v}_{\mathrm{a}}\left(\mathrm{VO}_{\mathrm{B}} \mathrm{V}\right)[45,58]$. The frequency of the $v_{\mathrm{s}}\left(\mathrm{V}=\mathrm{O}_{\mathrm{A}}\right)$ mode in $\mathrm{V}_{2} \mathrm{O}_{5}-\mathrm{PEO}-1$ and $\mathrm{V}_{2} \mathrm{O}_{5}-\mathrm{PEO}-2$ is observed at $988 \mathrm{~cm}^{-}$ ${ }^{1}$ which is clearly downshifted to lower frequencies compared to the frequency of the $v_{\mathrm{s}}\left(\mathrm{V}=\mathrm{O}_{\mathrm{A}}\right)$ mode in $\mathrm{V}_{2} \mathrm{O}_{5}$ xerogels (Figure 5b). The downshifting of the $\mathrm{v}_{\mathrm{s}}\left(\mathrm{V}=\mathrm{O}_{\mathrm{A}}\right)$ mode frequency is attributed to either direct interaction of the ether oxygen of PEO with the vanadyl oxygen in a similar manner as proposed for $\mathrm{H}_{2} \mathrm{O}[45,59]$, or from PEO interacting with $\mathrm{H}_{2} \mathrm{O}$ that alters the strength of hydrogen bonding between $\mathrm{H}_{2} \mathrm{O}$ coordinated to the vanadyl oxygen. Leroux et al. observed that for nanocomposites composed of alternating $\mathrm{V}_{2} \mathrm{O}_{5}$ sheets and polymer layers, the $v_{\mathrm{s}}\left(\mathrm{V}=\mathrm{O}_{\mathrm{A}}\right)$ mode frequency shifted to lower wavenumbers with the incorporation of polymers [60]. The shift in the position of the $v_{\mathrm{S}}\left(\mathrm{V}=\mathrm{O}_{\mathrm{A}}\right)$ mode was explained by a bonding interaction between the polymer and the inorganic $\mathrm{V}_{2} \mathrm{O}_{5}$ framework. A comparable shift of the frequency of the $v_{\mathrm{s}}\left(\mathrm{V}=\mathrm{O}_{\mathrm{A}}\right)$ band was attributed to hydrogen bonding within a $\mathrm{V}_{2} \mathrm{O}_{5}$-polypyrrole nanocomposite material [61]. Prior work has shown that frequency shifts of the vanadyl oxygen stretching mode can be correlated with changes in the vanadium-oxygen bond lengths [62]. The lower frequency of the $\mathrm{v}_{\mathrm{s}}\left(\mathrm{V}=\mathrm{O}_{\mathrm{A}}\right)$ mode within the $\mathrm{V}_{2} \mathrm{O}_{5}-\mathrm{PEO}$ nanocomposites is consistent with a longer bond distance and lowering bond strength based on interaction with PEO. In addition to the primary band at $998 \mathrm{~cm}^{-1}$ within the infrared spectrum of the $\mathrm{V}_{2} \mathrm{O}_{5}$ xerogel, a band was observed at $925 \mathrm{~cm}^{-1}$ which has been attributed to a $\mathrm{H}_{2} \mathrm{O}-\mathrm{V}$ vibrational mode [63]. The absence of the band at $925 \mathrm{~cm}^{-1}$ within the $\mathrm{V}_{2} \mathrm{O}_{5}$-PEO nanocomposites suggests that the interaction of $\mathrm{H}_{2} \mathrm{O}$ with the $\mathrm{V}_{2} \mathrm{O}_{5}$ lattice within the nanocomposites has been altered compared with the $\mathrm{V}_{2} \mathrm{O}_{5}$ xerogels. 
The infrared spectrum of PEO and assignments of PEO vibrational modes have been previously reported $[64,65]$. The infrared spectrum of a pure, bulk PEO sample is shown in Figure 5. Absorptions located between 3000 and $2700 \mathrm{~cm}^{-1}$ correspond to C-H stretching modes [64]. The $\mathrm{V}_{2} \mathrm{O}_{5}$-PEO nanocomposites show the presence of PEO within the samples as supported by the presence of bands at 2943 and $2880 \mathrm{~cm}^{-1}$ corresponding to $\mathrm{C}-\mathrm{H}$ stretches of PEO. In pure PEO, the 1114 and $1078 \mathrm{~cm}^{-1}$ bands are associated with predominantly C-O-C stretching modes of PEO (Figure 4) [64]. The intensities of the CO-C peaks are very weak in $\mathrm{V}_{2} \mathrm{O}_{5}$-PEO-1 but increase with higher PEO content in $\mathrm{V}_{2} \mathrm{O}_{5^{-}}$ PEO-2. The presence of triplet C-O-C stretching bands has been correlated with PEO within a crystalline phase [66-68]. The presence of triplet C-O-C stretching modes in the infrared spectrum of PEO indicates that the bulk PEO sample possessed either a crystalline or semi-crystalline phase, while PEO exists in an amorphous phase in $\mathrm{V}_{2} \mathrm{O}_{5^{-}}$PEO nanocomposites. Additional PEO absorptions were observed in the ATR-FTIR spectrum of the $\mathrm{V}_{2} \mathrm{O}_{5}$-PEO-2 nanocomposite. In contrast to the 1360 and $1342 \mathrm{~cm}^{-1} \mathrm{CH}_{2}$ wagging absorptions observed in pure PEO, a single absorption at $1353 \mathrm{~cm}^{-1}$ was observed. The occurrence of a single $\mathrm{CH}_{2}$ wagging absorption has been previously associated with an amorphous state of PEO [66]. The presence of PEO bands in the nanocomposite materials and the downshift of $v_{\mathrm{s}}\left(\mathrm{V}=\mathrm{O}_{\mathrm{A}}\right)$ stretching mode suggests that the PEO has been intercalated within the $\mathrm{V}_{2} \mathrm{O}_{5}$ layers and that the presence of PEO within the interlayer alters the vanadyl oxygen force constant and bond distance.

In addition to the presence of $\mathrm{V}_{2} \mathrm{O}_{5}$ and PEO vibrational modes, the ATR-FTIR spectrum of the $\mathrm{V}_{2} \mathrm{O}_{5}$ and $\mathrm{V}_{2} \mathrm{O}_{5}$-PEO samples showed bands due to $\mathrm{O}-\mathrm{H}$ stretching and $\mathrm{H}-\mathrm{O}-\mathrm{H}$ bending modes of chemically bound water within structure [69]. The presence of 
structural water is consistent with the XRD and TGA data. The $\mathrm{V}_{2} \mathrm{O}_{5}$ xeorgel shows a high frequency $\mathrm{O}-\mathrm{H}$ stretching band at $3568 \mathrm{~cm}^{-1}$, which has also been observed in previous infrared spectra of $\mathrm{V}_{2} \mathrm{O}_{5} \cdot \mathrm{nH}_{2} \mathrm{O}[45,70]$. The high frequency mode at $3568 \mathrm{~cm}^{-1}$ has been attributed to the asymmetric stretching mode, $v_{\text {as }}\left(\mathrm{OH}_{2}\right)$, of water and is proposed as originating from $\mathrm{OH}$ vibrations relatively free from hydrogen bonding [45]. The frequencies of the $\mathrm{O}-\mathrm{H}$ stretching modes are affected by hydrogen bonding with $\mathrm{V}=\mathrm{O}$ groups [71]. The $3568 \mathrm{~cm}^{-1}$ band was not observed in the infrared spectra of the $\mathrm{V}_{2} \mathrm{O}_{5^{-}}$ PEO nanocomposites. Instead, broad O-H absorptions were observed at $\sim 3300 \mathrm{~cm}^{-1}$, which supports that $\mathrm{H}_{2} \mathrm{O}$ within $\mathrm{V}_{2} \mathrm{O}_{5}$-PEO nanocomposites exhibit a greater degree of hydrogen bonding with either $\mathrm{V}_{2} \mathrm{O}_{5}$, $\mathrm{PEO}$ or both.

\subsection{Raman spectroscopic analysis of $\mathrm{V}_{2} \mathrm{O}_{5}$ xerogels and $\mathrm{V}_{2} \mathrm{O}_{5}$-PEO nanocomposites}

Raman spectroscopy was also used to probe the structure of the $\mathrm{V}_{2} \mathrm{O}_{5}-\mathrm{PEO}$ nanocomposites. The vibrational mode assignments and Raman spectra of $\mathrm{V}_{2} \mathrm{O}_{5}$ xerogels at various levels of hydration have been previously reported [45] and have been shown to be related to vibrations of crystalline orthorhombic $\mathrm{V}_{2} \mathrm{O}_{5}$ [58]. The $\mathrm{V}_{2} \mathrm{O}_{5}$ structure can be described by packing of $\mathrm{V}_{2} \mathrm{O}_{5}$ layers along the $\mathrm{c}$ axis of the unit cell. Each layer is built up from edge and corner-sharing $\mathrm{VO}_{5}$ square pyramids $[58,72]$. Differences between the vibrations of crystalline orthorhombic $\mathrm{V}_{2} \mathrm{O}_{5}$ and hydrated $\mathrm{V}_{2} \mathrm{O}_{5}$ xerogels have been attributed to the interaction of coordinated water molecules which were trapped between layers and held firmly in place, thus restricting or altering certain Raman-active vibrations [59]. 
Figure 6 shows the Raman spectra of $\mathrm{V}_{2} \mathrm{O}_{5}$ and $\mathrm{V}_{2} \mathrm{O}_{5}$-PEO nanocomposites. The vibrational bands observed for the Raman spectrum of the $\mathrm{V}_{2} \mathrm{O}_{5}$ xerogels (Figure 6a) are similar to those previously reported for $\mathrm{V}_{2} \mathrm{O}_{5} \cdot 1.6 \mathrm{H}_{2} \mathrm{O}$ xerogels [44, 45]. Compared with the bands of $\mathrm{V}_{2} \mathrm{O}_{5}$ xerogels, significant changes in the Raman spectra were observed for the $\mathrm{V}_{2} \mathrm{O}_{5}$-PEO nanocomposites. Bands at 890,512 , and $670 \mathrm{~cm}^{-1}$ have been assigned to modes due to $v\left(\mathrm{~V}=\mathrm{O}_{\mathrm{A}}\right)$ stretching, symmetric stretching $v_{\mathrm{S}}\left(\mathrm{V}-\mathrm{O}_{\mathrm{B}}-\mathrm{V}\right)$ of edge-shared oxygen and vanadium atoms, and $v\left(\mathrm{~V}_{2}-\mathrm{O}\right)$ stretching of doubly coordinated oxygen, respectively $[58,72]$. The interaction of $\mathrm{V}_{2} \mathrm{O}_{5}$ with $\mathrm{H}_{2} \mathrm{O}$ occurs primarily with the vandyl oxygen bond, $\mathrm{V}=\mathrm{O}$, via either (i) hydrogen bonding to the vanadyl oxygen or (ii) coordination of oxygen of $\mathrm{H}_{2} \mathrm{O}$ with the axial vanadium of the vandyl oxygen, as supported by prior work $[34,59]$. Based on these interactions, vibrational modes that are strongly influenced by coordination with the vandyl oxygen bond are expected to be more strongly affected than other vibrational modes.

In particular, bands 890 and $135 \mathrm{~cm}^{-1}$ were either significantly reduced in relative intensity or absent within the $\mathrm{V}_{2} \mathrm{O}_{5}$-PEO nanocomposites. In crystalline $\mathrm{V}_{2} \mathrm{O}_{5}$, bands at 145 and $146 \mathrm{~cm}^{-1}$ arise from lattice vibrational modes (restricted $T_{z}$ and $R_{y}$ ) [58], and these bands are strongly associated with the layered structure [46]. Similar lattice vibrational modes are observed in $\mathrm{V}_{2} \mathrm{O}_{5}$ xerogels at 155 and $135 \mathrm{~cm}^{-1}$ [45]. The intensities of the lattice modes were found to decrease with Li intercalation [44]. In our case, the intensities of low frequency lattice vibrations were found to be significantly altered in both $\mathrm{V}_{2} \mathrm{O}_{5}$-PEO-1 and $\mathrm{V}_{2} \mathrm{O}_{5}$-PEO-2, which may be due to the interaction of PEO with the $\mathrm{V}_{2} \mathrm{O}_{5}$ lattice that alters the lattice vibrations. Changes in the relative intensity of the 135 $\mathrm{cm}^{-1}$ band provide insight into the nature of PEO and $\mathrm{H}_{2} \mathrm{O}$ interaction with the $\mathrm{V}_{2} \mathrm{O}_{5}$ 
lattice. Prior work showed that the presence and intensity of the $135 \mathrm{~cm}^{-1}$ band in $\mathrm{V}_{2} \mathrm{O}_{5}$ xerogels is highly dependent on the amount of interlayer water [45]. The $135 \mathrm{~cm}^{-1}$ band was observed as a strong peak at relatively high levels of hydration, $\mathrm{V}_{2} \mathrm{O}_{5} \cdot 1.2 \mathrm{H}_{2} \mathrm{O}$ and $\mathrm{V}_{2} \mathrm{O}_{5} \cdot 1.6 \mathrm{H}_{2} \mathrm{O}$, however for $\mathrm{V}_{2} \mathrm{O}_{5} \cdot 0.6 \mathrm{H}_{2} \mathrm{O}$, the $135 \mathrm{~cm}^{-1}$ was observed as a shoulder and was not observed at $\mathrm{V}_{2} \mathrm{O}_{5} \cdot 0.4 \mathrm{H}_{2} \mathrm{O}$ and crystalline $\mathrm{V}_{2} \mathrm{O}_{5}$ [45].

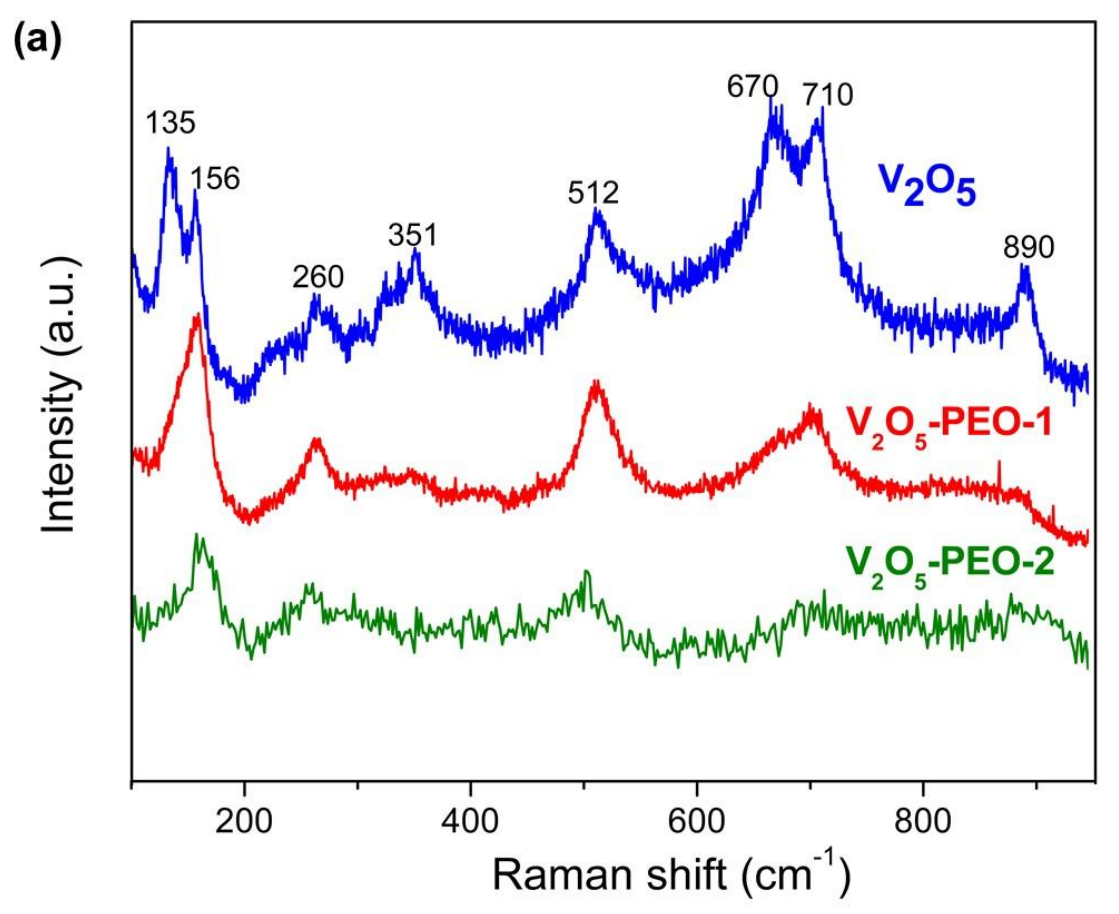

(b)

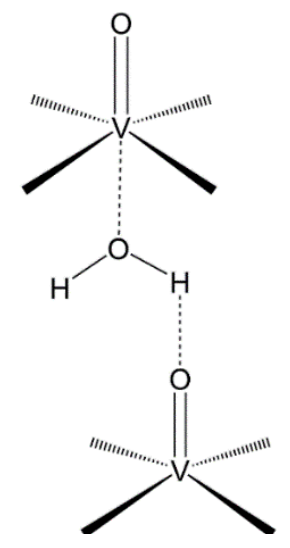

(c)

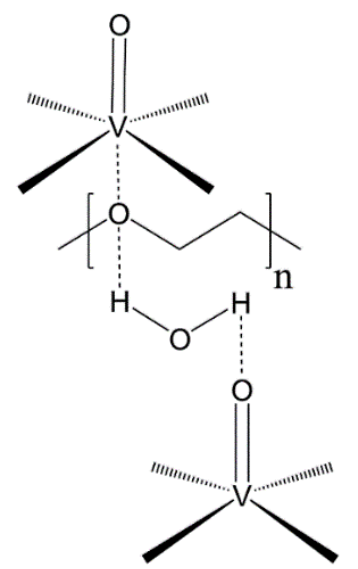

Figure 6. (a) Raman spectra of $\mathrm{V}_{2} \mathrm{O}_{5}$ xerogel, $\mathrm{V}_{2} \mathrm{O}_{5}$-PEO-1 and $\mathrm{V}_{2} \mathrm{O}_{5}$-PEO-2 in the 100 $\mathrm{cm}^{-1}$ to $950 \mathrm{~cm}^{-1}$ region; (b) Representation of possible coordination of interlayer $\mathrm{H}_{2} \mathrm{O}$ within $\mathrm{V}_{2} \mathrm{O}_{5}$ via hydrogen bonding; (c) Representation of possible coordination of $\mathrm{V}_{2} \mathrm{O}_{5}$ 
with both interlayer $\mathrm{H}_{2} \mathrm{O}$ and $\mathrm{PEO}$ via hydrogen bonding; schematics do not represent steric effects and PEO chain conformation.

Our TGA analysis supports that the $\mathrm{V}_{2} \mathrm{O}_{5}$-PEO nanocomposites and $\mathrm{V}_{2} \mathrm{O}_{5}$ xerogel all contain a similar amount of structural $\mathrm{H}_{2} \mathrm{O}$ (Figure $\mathrm{S} 1$ ), however the relative intensity of the $135 \mathrm{~cm}^{-1}$ band is significantly different. The presence of a $135 \mathrm{~cm}^{-1}$ shoulder within $\mathrm{V}_{2} \mathrm{O}_{5}$-PEO-1 suggests that both $\mathrm{PEO}$ and $\mathrm{H}_{2} \mathrm{O}$ interact with the $\mathrm{V}_{2} \mathrm{O}_{5}$ lattice. However, the relative intensity of the $135 \mathrm{~cm}^{-1}$ band in $\mathrm{V}_{2} \mathrm{O}_{5}-\mathrm{PEO}-1$ is significantly lower than for the $\mathrm{V}_{2} \mathrm{O}_{5}$ xerogel, and for $\mathrm{V}_{2} \mathrm{O}_{5}$-PEO-2, the $135 \mathrm{~cm}^{-1}$ band is not appreciably observed. Based on the correlation of the intensity of the $135 \mathrm{~cm}^{-1}$ band with the amount of interlayer $\mathrm{H}_{2} \mathrm{O}$ [45], the lower relative intensity of the $135 \mathrm{~cm}^{-1}$ band for the $\mathrm{V}_{2} \mathrm{O}_{5^{-}}$ PEO-1 and $\mathrm{V}_{2} \mathrm{O}_{5}$-PEO-2 nanocomposites compared with the $\mathrm{V}_{2} \mathrm{O}_{5}$ xerogel despite similar amounts of $\mathrm{H}_{2} \mathrm{O}$ suggests that $\mathrm{PEO}$ rather than $\mathrm{H}_{2} \mathrm{O}$ preferentially coordinates with the $\mathrm{V}_{2} \mathrm{O}_{5}$ lattice. Based on this observation, it is possible that the interaction with PEO alters the relative intensity of $\mathrm{V}_{2} \mathrm{O}_{5}$ lattice modes. Prior work showed that by reducing the interaction of $\mathrm{V}_{2} \mathrm{O}_{5}$ layers resulted in the potential energy distribution of low frequency vibrational modes being redistributed to other coordinates [72].

Previous reports have characterized the nature interactions of $\mathrm{H}_{2} \mathrm{O}$ with $\mathrm{V}_{2} \mathrm{O}_{5}$ and suggested specific types of hydrogen bonding configurations between $\mathrm{H}_{2} \mathrm{O}$ and the vandayl oxygen group $[34,59]$. Based on these models, Figure $6 b$ illustrates a coordination geometry of interlayer $\mathrm{H}_{2} \mathrm{O}$ within $\mathrm{V}_{2} \mathrm{O}_{5}$ via hydrogen bonding. Figure $6 \mathrm{c}$ represents postulated coordination of interlayer $\mathrm{PEO}$ and $\mathrm{H}_{2} \mathrm{O}$ with $\mathrm{V}_{2} \mathrm{O}_{5}$ via hydrogen bonding. Further analysis is needed to determine the specific coordination environments of $\mathrm{H}_{2} \mathrm{O}$ and $\mathrm{PEO}$ within the $\mathrm{V}_{2} \mathrm{O}_{5}$ layers, which we expect to vary depending on the 
relative composition of $\mathrm{H}_{2} \mathrm{O}$ and polymer within the structure. Additionally, we did not observe the band at $822 \mathrm{~cm}^{-1}$, corresponding to $\mathrm{CH}_{2}$ rocking modes of $\mathrm{PEO}$. This is mainly due to the combination of low excitation laser power used for the Raman analysis and the low concentration of PEO present in the composites.

\subsection{Electrochemical evaluation of $\mathrm{V}_{2} \mathrm{O}_{5}$ xerogels and $\mathrm{V}_{2} \mathrm{O}_{5}$-PEO nanocomposites}

The Mg-ion charge storage capacity of the $\mathrm{V}_{2} \mathrm{O}_{5}$ xerogels and $\mathrm{V}_{2} \mathrm{O}_{5}$-PEO nanocomposites were determined using galvanostaic charge/discharge tests. Vanadium pentoxide can reversibly electrochemically store $\mathrm{Mg}$-ions and electrons within its structure, which can be described by the following equation.

$$
\mathrm{V}_{2} \mathrm{O}_{5}+\mathrm{xMg}^{2+}+2 x e^{-} \rightleftharpoons \mathrm{Mg}_{x} \mathrm{~V}_{2} \mathrm{O}_{5}
$$

Shown in Figure 7 are the galvanostatic charge/discharge profiles recorded at a mass-normalized current density of $10 \mathrm{~mA} / \mathrm{g}$. The sloping voltage profile is similar to that observed for Li-ion intercalation into $\mathrm{V}_{2} \mathrm{O}_{5} \cdot \mathrm{nH}_{2} \mathrm{O}$ xerogels [73]. For storage of $\mathrm{Mg}$ ions within $\mathrm{V}_{2} \mathrm{O}_{5}$, prior calculations support that $\mathrm{H}_{2} \mathrm{O}$ content can significantly influence voltage for $\mathrm{Mg}$-ion insertion into $\mathrm{V}_{2} \mathrm{O}_{5}$ xerogels and can result in a sloping voltage profile [35]. We consider that due to the well-established ion coordination ability of PEO it is possible that interlayer PEO may affect the voltage of $\mathrm{Mg}$-ion insertion into $\mathrm{V}_{2} \mathrm{O}_{5}$ in a manner similar to $\mathrm{H}_{2} \mathrm{O}$, however further investigation is needed to determine the effects of interlayer $\mathrm{PEO}$ and $\mathrm{H}_{2} \mathrm{O}$ on $\mathrm{Mg}$-ion insertion voltage.

The $\mathrm{V}_{2} \mathrm{O}_{5}$ xerogels showed a Mg-ion charge storage capacity of $19 \mathrm{mAh} / \mathrm{g}(\mathrm{C} / 10$ discharge rate), which is in the range of previous reports [22]. Compared with the $\mathrm{V}_{2} \mathrm{O}_{5}$ xerogel, the $\mathrm{V}_{2} \mathrm{O}_{5}$-PEO-1 nanocomposite showed a significantly higher $\mathrm{Mg}$-ion capacity 
of $100.3 \mathrm{mAh} \mathrm{g}^{-1}$, which is $\sim 5$ times higher than the $\mathrm{V}_{2} \mathrm{O}_{5}$ xerogel capacity. The $\mathrm{V}_{2} \mathrm{O}_{5^{-}}$PEO-2 cathode exhibited a capacity of $53.7 \mathrm{mAh} \mathrm{g}^{-1}$ which is higher than the $\mathrm{V}_{2} \mathrm{O}_{5}$ xerogel but lower than $\mathrm{V}_{2} \mathrm{O}_{5}$-PEO-1.

The $\mathrm{Mg}$-ion capacity of $0.06,0.34$, and 0.18 per $\mathrm{V}_{2} \mathrm{O}_{5}$ formula unit was determined (i.e. $\mathrm{x}$ in $\mathrm{Mg}_{\mathrm{x}} \mathrm{V}_{2} \mathrm{O}_{5}$ ) for the $\mathrm{V}_{2} \mathrm{O}_{5}$ xerogel, $\mathrm{V}_{2} \mathrm{O}_{5}$-PEO-1, and $\mathrm{V}_{2} \mathrm{O}_{5}$-PEO-2 materials respectively. The higher Mg-ion storage capacity of $\mathrm{V}_{2} \mathrm{O}_{5}-\mathrm{PEO}-1$ compared with $\mathrm{V}_{2} \mathrm{O}_{5}$ xerogel is related to the larger interlayer spacing and the specific nature of $\mathrm{V}_{2} \mathrm{O}_{5}$, polymer, and $\mathrm{H}_{2} \mathrm{O}$ interactions within the structure, as discussed further below. Clearly, interlayer spacing is not the only factor since $\mathrm{V}_{2} \mathrm{O}_{5}$-PEO-2 showed higher interlayer spacing compared to $\mathrm{V}_{2} \mathrm{O}_{5}$-PEO-1 from XRD and TEM analysis, however $\mathrm{V}_{2} \mathrm{O}_{5}$-PEO-2 exhibited lower Mg-ion specific capacity than $\mathrm{V}_{2} \mathrm{O}_{5}$-PEO-1.

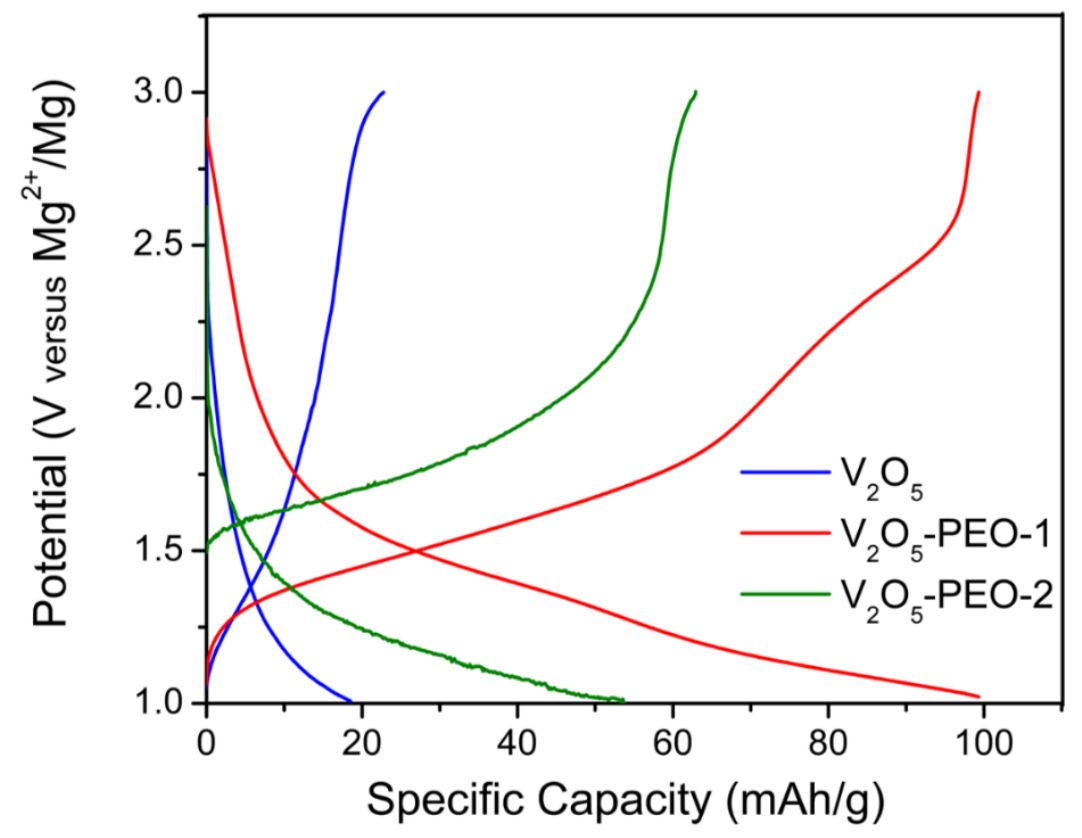

Figure 7. Galvanostatic charge-discharge voltage profiles of $\mathrm{V}_{2} \mathrm{O}_{5}, \mathrm{~V}_{2} \mathrm{O}_{5}-\mathrm{PEO}-1$ and $\mathrm{V}_{2} \mathrm{O}_{5}$-PEO-2 acquired at a mass-normalized current of $10 \mathrm{~mA} \mathrm{~g}^{-1}$; electrolyte: $1 \mathrm{M}$ $\mathrm{Mg}\left(\mathrm{ClO}_{4}\right)_{2}$ in dried acetonitrile; counter: carbon; reference: $\mathrm{Mg}$ metal. 
In order to further understand the $\mathrm{Mg}$-ion charge storage within $\mathrm{V}_{2} \mathrm{O}_{5}$ and $\mathrm{V}_{2} \mathrm{O}_{5^{-}}$ PEO nanocomposites, cyclic voltammograms $(\mathrm{CV})$ at different scan rates were acquired and analyzed. Figure $8 \mathrm{a}$ shows the $\mathrm{CV}$ curves of $\mathrm{V}_{2} \mathrm{O}_{5}, \mathrm{~V}_{2} \mathrm{O}_{5}-\mathrm{PEO}-1$ and $\mathrm{V}_{2} \mathrm{O}_{5}-\mathrm{PEO}-2$ at a scan rate of $2.5 \mathrm{mV} / \mathrm{s}$. The $\mathrm{V}_{2} \mathrm{O}_{5}$ xerogels show an anodic peak at $\sim 1.6 \mathrm{~V}$ vs $\mathrm{Mg}^{2+} / \mathrm{Mg}$. Compared to $\mathrm{V}_{2} \mathrm{O}_{5}$ xerogels and $\mathrm{V}_{2} \mathrm{O}_{5}$-PEO-2, the $\mathrm{V}_{2} \mathrm{O}_{5}$-PEO-1 nanocomposite showed higher current per mass of material indicating that the introduction of PEO within $\mathrm{V}_{2} \mathrm{O}_{5}$ improved the Mg-ion charge storage capacity. 

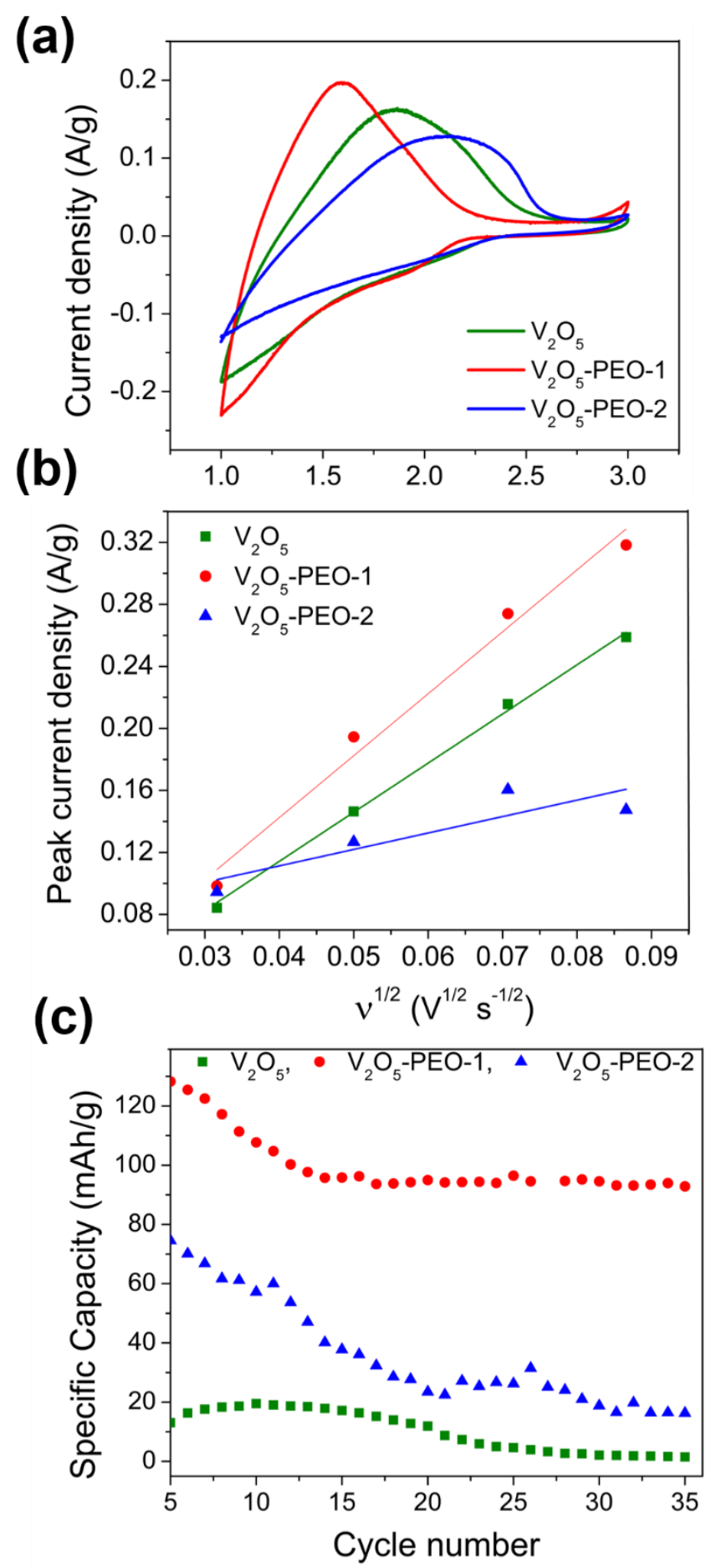

Figure 8. (a) Cyclic voltammograms of $\mathrm{V}_{2} \mathrm{O}_{5}, \mathrm{~V}_{2} \mathrm{O}_{5}-\mathrm{PEO}-1$ and $\mathrm{V}_{2} \mathrm{O}_{5}-\mathrm{PEO}-2$ recorded at a scan rate of $2.5 \mathrm{mV} / \mathrm{s}$; electrolyte: $1 \mathrm{M} \mathrm{Mg}\left(\mathrm{ClO}_{4}\right)_{2}$ in dried acetonitrile; counter: carbon cloth; reference: $\mathrm{Mg}$ metal; (b) Plot of the peak current density as a function of the square root of scan rate $(v)$ showing a linear response (c) Cycling performance of $\mathrm{V}_{2} \mathrm{O}_{5}$, $\mathrm{V}_{2} \mathrm{O}_{5}$-PEO-1 and $\mathrm{V}_{2} \mathrm{O}_{5}$-PEO-2 recorded at $10 \mathrm{~mA} / \mathrm{g}$ constant current density for 30 cycles. All electrodes were pre-conditioned by charging and discharging 5 cycles prior to cycling. 
At higher scan rates of 5.0 and $7.5 \mathrm{mV} \mathrm{s}^{-1}$ (Figure $\mathrm{S} 3$ ), the $\mathrm{V}_{2} \mathrm{O}_{5}$-PEO-1 nanocomposite also showed higher currents than $\mathrm{V}_{2} \mathrm{O}_{5}$ xerogels and $\mathrm{V}_{2} \mathrm{O}_{5}$-PEO-2. At the higher scan rates, the peaks of the $\mathrm{V}_{2} \mathrm{O}_{5}$ xerogels and $\mathrm{V}_{2} \mathrm{O}_{5}$-PEO-2 were shifted to higher voltages, which is due to resistances within the electrode materials. We note that the scan rates applied to evaluate the $\mathrm{Mg}^{2+}$ ion storage capacity are much higher than that of previously reported scan rates used for thin film configurations [13], which suggests that the nanocomposite morphology provides an electrode architecture that can be used for practical electrodes rather than only thin films.

The Mg-ion charge storage kinetics were investigated by analysis of the cyclic voltammograms acquired at different scan rates. Shown in Figure $8 \mathrm{~b}$ is the plot of peak current density vs. (scan rate, $v)^{1 / 2}$ for $\mathrm{V}_{2} \mathrm{O}_{5}, \mathrm{~V}_{2} \mathrm{O}_{5}-\mathrm{PEO}-1$ and $\mathrm{V}_{2} \mathrm{O}_{5}-\mathrm{PEO}-2$ at different scan rates. The plots exhibit a linear response with respect to (scan rate $)^{1 / 2} \cdot \mathrm{V}_{2} \mathrm{O}_{5}-\mathrm{PEO}-1$ showed a higher slope than $\mathrm{V}_{2} \mathrm{O}_{5}$ or $\mathrm{V}_{2} \mathrm{O}_{5}$-PEO-2. Based on the linear trends of peak current density vs. (scan rate, $v)^{1 / 2}, \mathrm{Mg}^{2+}$ diffusion coefficients were determined using the Randles-Sevcik equation:

$$
I_{p}=0.4463 z F A C \sqrt{\frac{z F v D}{R T}}
$$

where $I_{p}$ is the peak current value (Amps), $z$ is the number of exchanged electrons $(z=2)$, $\mathrm{F}$ is the Faraday constant $\left(96,485 \mathrm{C} \mathrm{mol}^{-1}\right), \mathrm{A}$ is the electrode geometric area $\left(\mathrm{cm}^{2}\right), \mathrm{C}$ is the $\mathrm{Mg}^{2+}$ concentration within the lattice $\left(\mathrm{mol} \mathrm{cm}{ }^{-3}\right), v$ is the scan rate $\left(\mathrm{V} \mathrm{s}^{-1}\right), \mathrm{D}$ is the diffusion coefficient $\left(\mathrm{cm}^{2} \mathrm{~s}^{-1}\right)$, $\mathrm{R}$ is the gas constant $\left(\mathrm{J} \mathrm{K}^{-1} \mathrm{~mol}^{-1}\right)$, and $\mathrm{T}$ is the temperature (K) [74]. The $\mathrm{Mg}^{2+}$ diffusion coefficients, $D_{M g^{2+}}$, were obtained from the 
slopes of the peak current vs. $v^{1 / 2}$ (Figure $8 \mathrm{~b}$ ). For the $\mathrm{V}_{2} \mathrm{O}_{5}$ xerogel, $D_{M g^{2+}}$, was determined to be $2.4 \times 10^{-11} \mathrm{~cm}^{2} \mathrm{~s}^{-1}$, which is in the range of previously reported values for $\mathrm{Mg}^{2+}$ diffusion coefficients [10]. The $\mathrm{V}_{2} \mathrm{O}_{5}$-PEO-1 nanocomposite showed a higher $\mathrm{Mg}^{2+}$ diffusion coefficient of $4.7 \times 10^{-11} \mathrm{~cm}^{2} \mathrm{~s}^{-1}$, which is 2 times higher than the $\mathrm{Mg}^{2+}$ diffusion coefficient for the $\mathrm{V}_{2} \mathrm{O}_{5}$ xerogel. The $\mathrm{V}_{2} \mathrm{O}_{5}$-PEO-2 nanocomposites had a $\mathrm{Mg}^{2+}$ diffusion coefficient of $2.5 \times 10^{-12} \mathrm{~cm}^{2} \mathrm{~s}^{-1}$, which was lower than that observed for either the $\mathrm{V}_{2} \mathrm{O}_{5}$ xerogel or the $\mathrm{V}_{2} \mathrm{O}_{5}$-PEO-1 nanocomposite.

The higher diffusion coefficient for $\mathrm{V}_{2} \mathrm{O}_{5}$-PEO-1 compared with the $\mathrm{V}_{2} \mathrm{O}_{5}$ xerogel is consistent with more facile $\mathrm{Mg}^{2+}$ diffusion resulting from the larger interlayer spacing (Figures 2 and 4) and the interaction of the polymer with the negatively charged $\mathrm{V}_{2} \mathrm{O}_{5}$ host lattice which shields the $\mathrm{Mg}^{2+}$ from direct interaction with $\mathrm{V}_{2} \mathrm{O}_{5}$. TGA indicates that $\mathrm{V}_{2} \mathrm{O}_{5}$-PEO-1 and $\mathrm{V}_{2} \mathrm{O}_{5}$ xerogel contain similar amounts of structural water, however the Raman spectra (Figure 6a) support that polymer interacts preferentially with the $\mathrm{V}_{2} \mathrm{O}_{5}$ lattice leading to $\mathrm{H}_{2} \mathrm{O}$ within the interlayer. For $\mathrm{V}_{2} \mathrm{O}_{5} \cdot 1.4 \mathrm{H}_{2} \mathrm{O}$ xerogels, prior work identified three different types of $\mathrm{H}_{2} \mathrm{O}$ within the structure including $\mathrm{H}_{2} \mathrm{O}$ that was hydrogen-bonded with other $\mathrm{H}_{2} \mathrm{O}$ molecules rather than strongly associated with the lattice [72]. $\mathrm{H}_{2} \mathrm{O}$ that is less strongly bound with $\mathrm{V}_{2} \mathrm{O}_{5}$ can result in improved ion transport due to the coupling of $\mathrm{H}_{2} \mathrm{O}$ with higher freedom of motion with ion diffusion as supported by prior work [70]. The higher Mg-ion diffusion within $\mathrm{V}_{2} \mathrm{O}_{5}-\mathrm{PEO}-1$ is therefore attributed to improved mobility of Mg-ion within the expanded interlayer spacing due to coordination of $\mathrm{Mg}$-ions with interlayer $\mathrm{H}_{2} \mathrm{O}$ and polymer shielding of the interaction of $\mathrm{Mg}^{2+}$ with $\mathrm{V}_{2} \mathrm{O}_{5}$. 
The $\mathrm{Mg}^{2+}$ diffusion coefficient of $\mathrm{V}_{2} \mathrm{O}_{5}$-PEO-2 was lower than that of the $\mathrm{V}_{2} \mathrm{O}_{5}$ xerogel or $\mathrm{V}_{2} \mathrm{O}_{5}$-PEO-1. $\mathrm{V}_{2} \mathrm{O}_{5}$-PEO-2 had the highest amount of PEO and the largest interlayer spacing. The lower diffusion coefficient and capacity $\mathrm{V}_{2} \mathrm{O}_{5}$-PEO-2 compared with $\mathrm{V}_{2} \mathrm{O}_{5}$-PEO-1 indicates that larger interlayer spacing is not the only contributor to electrochemical Mg-ion charge storage. Mg-ion diffusion is therefore not only affected by the interlayer spacing, but also the interlayer composition. Higher amounts of PEO may result in lower performance due to (i) lower diffusion of $\mathrm{Mg}$-ions with PEO-rich regions, (ii) lower electronic conductivity by electronically insulating PEO, (iii) coordination of $\mathrm{PEO}$ with $\mathrm{V}_{2} \mathrm{O}_{5}$ lattice that blocks $\mathrm{Mg}$-ion sites. The high peak current density of $\mathrm{V}_{2} \mathrm{O}_{5}$-PEO-1 at 2.5, 5.0 and $7.5 \mathrm{mV} / \mathrm{s}$ scan rates indicates a fast charge transfer process due to the presence of a specific amount of PEO that interacts with the host lattice and enlarges interlayer spacing without hindering the electrochemical activity of $\mathrm{V}_{2} \mathrm{O}_{5}$. Higher amounts of PEO results in lower electrochemical performance, especially at high rates (Figure $\mathrm{S} 3$ ).

To determine the reversibility of $\mathrm{Mg}$-ion insertion within the materials, the cycling performance of the $\mathrm{V}_{2} \mathrm{O}_{5}$-PEO nanocomposites were determined by galvanostatic charge-discharge conducted at a constant current density of $10 \mathrm{~mA} \mathrm{~g}^{-1}$ (Figure 8c). Prior to analyzing the cycling performance, the electrodes were conditioned for 5 cycles to establish stable electrochemistry. The higher specific capacity of $\mathrm{V}_{2} \mathrm{O}_{5}$-PEO-1 over the other samples is maintained over 35 cycles. The initial specific capacity of $\mathrm{V}_{2} \mathrm{O}_{5}-\mathrm{PEO}-1$ gradually dropped from $125 \mathrm{mAh} \mathrm{g}^{-1}$ to $96 \mathrm{mAh} \mathrm{g}^{-1}$ over the first 12 cycles and maintained $\sim 77 \%$ of its initial specific capacity over 35 cycles. The incorporation of PEO therefore improved the reversible cycling of $\mathrm{Mg}$-ion within the $\mathrm{V}_{2} \mathrm{O}_{5}$ structure. 
While the $\mathrm{V}_{2} \mathrm{O}_{5}$ xerogel electrode slowly dropped its initial specific capacity of 18.5 to $4.3 \mathrm{mAh} \mathrm{g}^{-1}, \mathrm{~V}_{2} \mathrm{O}_{5}$-PEO-2 electrode was constantly deteriorating its overall specific capacity from $76 \mathrm{mAh} \mathrm{g}^{-1}$, which is higher than that of $\mathrm{V}_{2} \mathrm{O}_{5}$, to $20 \mathrm{mAh} \mathrm{g}^{-1}$ with $\sim 74 \%$ of capacity loss over 35 cycles. The average coulombic efficiency of the $\mathrm{V}_{2} \mathrm{O}_{5}$-PEO-1 nanocomposite was $98.6 \%$, which was higher than the coulombic efficiencies of $\mathrm{V}_{2} \mathrm{O}_{5}$ and $\mathrm{V}_{2} \mathrm{O}_{5}$-PEO-2, which showed coulombic efficiencies of $84.7 \%$ and $89.2 \%$ respectively. Changes in the capacity of $\mathrm{V}_{2} \mathrm{O}_{5}$ - $\mathrm{PEO}$ nanocomposites during the first few cycles may be due to a number of possible factors including changes in the interlayer spacing and composition due to intercalation of $\mathrm{Mg}^{2+}$ and potential solvent cointercalation as previously reported for $\mathrm{V}_{2} \mathrm{O}_{5}$ xerogels [22].

To confirm that PEO was maintained within the $\mathrm{V}_{2} \mathrm{O}_{5}$-PEO nanocomposites after cycling within the electrolyte, FTIR-ATR spectra were obtained of the $\mathrm{V}_{2} \mathrm{O}_{5}$-PEO-1 and $\mathrm{V}_{2} \mathrm{O}_{5}$-PEO-2 electrodes before and after cycling. As presented in Figure S4, FTIR-ATR spectra show the presence of $\mathrm{C}-\mathrm{O}-\mathrm{C}$ stretching bands originating from $\mathrm{PEO}$ at similar relative intensities when normalized to the relative intensity of the $v_{\mathrm{S}}\left(\mathrm{V}=\mathrm{O}_{\mathrm{A}}\right)$ mode of $\mathrm{V}_{2} \mathrm{O}_{5}$ which provides evidence that PEO within nanocomposite materials is maintained after electrochemical cycling in the electrolyte. The nature of structural changes of the $\forall_{2} \Theta_{5}$ PEO nanocomposites during cycling is currently under investigation by our group and will be reported in a separate publication.

\section{Conclusions}

The interlayer spacing and interlayer composition of hydrated $\mathrm{V}_{2} \mathrm{O}_{5}$ xerogels was altered by incorporating poly(ethylene oxide) within the $\mathrm{V}_{2} \mathrm{O}_{5}$ layers as an approach to 
improve electrochemical storage of Mg-ions within the structure. The in-situ sol-gel synthesis method provides an effective approach to control the amount of PEO and interlayer spacing. From XRD, the interlayer spacing was shown to increase from $11.6 \AA$ for the $\mathrm{V}_{2} \mathrm{O}_{5}$ xerogels to $12.6 \AA$ and $13.6 \AA$ for the $\mathrm{V}_{2} \mathrm{O}_{5}$-PEO- 1 and $\mathrm{V}_{2} \mathrm{O}_{5}$-PEO-2 samples respectively. Higher amounts of PEO resulted in larger interlayer spacing. Infrared spectroscopy shows that the PEO interacts with the $\mathrm{V}_{2} \mathrm{O}_{5}$ lattice. Analysis of the Raman-active low frequency lattice modes of $\mathrm{V}_{2} \mathrm{O}_{5}$ supports that the polymer interacts with the $\mathrm{V}_{2} \mathrm{O}_{5}$ lattice and interaction of $\mathrm{H}_{2} \mathrm{O}$ with $\mathrm{V}_{2} \mathrm{O}_{5}$ is reduced compared with the $\mathrm{V}_{2} \mathrm{O}_{5}$ xerogel with similar amounts of structural $\mathrm{H}_{2} \mathrm{O}$.

The $\mathrm{V}_{2} \mathrm{O}_{5}$-PEO nanocomposites were shown to exhibit higher $\mathrm{Mg}^{2+}$ diffusion coefficients compared with the $\mathrm{V}_{2} \mathrm{O}_{5}$ xerogel. The $\mathrm{V}_{2} \mathrm{O}_{5}$-PEO-1 nanocomposite showed 2 times higher diffusion coefficient compared with the $\mathrm{V}_{2} \mathrm{O}_{5}$ xerogel, which is attributed to the enhanced Mg-ion transport within the interlayer that is facilitated by structural $\mathrm{H}_{2} \mathrm{O}$ that is not strongly bound with the $\mathrm{V}_{2} \mathrm{O}_{5}$ lattice. The incorporation of PEO between the $\mathrm{V}_{2} \mathrm{O}_{5}$ layers therefore shields the $\mathrm{Mg}^{2+}$ ions from strong interaction with the host lattice and improves $\mathrm{Mg}^{2+}$ mobility.

As a result of the structure of the $\mathrm{V}_{2} \mathrm{O}_{5}$-PEO nanocomposites, the Mg-ion charge storage capacity was $\sim 5$ times higher for $\mathrm{V}_{2} \mathrm{O}_{5}$-PEO-1 than the $\mathrm{V}_{2} \mathrm{O}_{5}$ xerogel. In particular, the $\mathrm{V}_{2} \mathrm{O}_{5}$-PEO-1 nanocomposite also exhibited significantly improved capacities compared with $\mathrm{V}_{2} \mathrm{O}_{5}$ xerogels at high scan rates. At higher PEO compositions, lower Mg-ion diffusion coefficients and capacities were observed which is attributed to higher resistances within the material. These results support that that not only interlayer spacing but importantly the nature of interlayer interactions between the $\mathrm{V}_{2} \mathrm{O}_{5}$ lattice, 
PEO, $\mathrm{H}_{2} \mathrm{O}$ and $\mathrm{Mg}$-ions, significant affect the $\mathrm{Mg}$-ion charge transport and storage. Designing layered materials with controlled interlayer interactions provides a new approach to modify the interaction between Mg-ions and the host lattice and develop improved cathodes for rechargeable magnesium batteries. Further work is aimed at characterizing the structural changes occurring during Mg-ion insertion and de-insertion within the nanocomposite materials and evaluating the electrochemical Mg-ion charge storage of the cathodes within electrolytes that allow reversible anodic Mg deposition and stripping and have wide voltage windows to enable viable rechargeable magnesium batteries.

\section{Acknowledgements}

The authors gratefully acknowledge funding from the National Science Foundation PREM (Grant No. DMR-1205670) and the Texas State University Research Enhancement Program (REP).

\section{Appendix A. Supporting information}

Supplementary data associated with this article can be found in the online version at http://dx.doi.org/

\section{References}

[1] N. Nitta, F.X. Wu, J.T. Lee, G. Yushin, Mater. Today, 18 (2015) 252-264.

[2] N. Liu, Z.D. Lu, J. Zhao, M.T. McDowell, H.W. Lee, W.T. Zhao, Y. Cui, Nat. Nanotechnol., 9 (2014) 187-192.

[3] X.L. Dong, L. Chen, J.Y. Liu, S. Haller, Y.G. Wang, Y.Y. Xia, Sci. Adv., 2 (2016) 8. 
[4] E. McCalla, A.M. Abakumov, M. Saubanere, D. Foix, E.J. Berg, G. Rousse, M.L. Doublet, D. Gonbeau, P. Novak, G. Van Tendeloo, R. Dominko, J.M. Tarascon, Science, 350 (2015) 1516-1521.

[5] D. Aurbach, G.S. Suresh, E. Levi, A. Mitelman, O. Mizrahi, O. Chusid, M. Brunelli, Adv. Mater., 19 (2007) 4260-4267.

[6] H.S. Kim, T.S. Arthur, G.D. Allred, J. Zajicek, J.G. Newman, A.E. Rodnyansky, A.G. Oliver, W.C. Boggess, J. Muldoon, Nature communications, 2 (2011) 427.

[7] R. Zhang, T.S. Arthur, C. Ling, F. Mizuno, J. Power Sources, 282 (2015) 630-638.

[8] D. Aurbach, Z. Lu, A. Schechter, Y. Gofer, H. Gizbar, R. urgeman, Y. Cohen, M. M., E. Levi, Nature, 407 (2000) 724-726.

[9] H.D. Yoo, I. Shterenberg, Y. Gofer, G. Gershinsky, N. Pour, D. Aurbach, Energy Environ. Sci., 6 (2013) 2265-2279.

[10] Y. Liang, H.D. Yoo, Y. Li, J. Shuai, H.A. Calderon, F.C. Robles Hernandez, L.C. Grabow, Y. Yao, Nano. Lett., 15 (2015) 2194-2202.

[11] P. Saha, M.K. Datta, O.I. Velikokhatnyi, A. Manivannan, D. Alman, P.N. Kumta, Prog. Mater. Sci., 66 (2014) 1-86.

[12] M.M. Huie, D.C. Bock, E.S. Takeuchi, A.C. Marschilok, K.J. Takeuchi, Coord. Chem. Rev., 287 (2015) 15-27.

[13] G. Gershinsky, H.D. Yoo, Y. Gofer, D. Aurbach, Langmuir, 29 (2013) 1096410972.

[14] P. Saha, P.H. Jampani, M.K. Datta, C.U. Okoli, A. Manivannan, P.N. Kumta, J. Electrochem. Soc., 161 (2014) A593-A598.

[15] R. Zhang, C. Ling, F. Mizuno, Chem. Commun., 51 (2015) 1487-1490.

[16] E. Lancry, E. Levi, A. Mitelman, S. Malovany, D. Aurbach, J. Solid State Chem., 179 (2006) 1879-1882.

[17] Y. NuLi, J. Yang, Y. Li, J. Wang, Chemical communications, 46 (2010) 3794-3796.

[18] X. Sun, P. Bonnick, L.F. Nazar, ACS Energy Lett., 1 (2016) 297-301.

[19] R. Mohtadi, F. Mizuno, Beilstein journal of nanotechnology, 5 (2014) 1291-1311.

[20] G.G. Amatucci, F. Badway, A. Singhal, B. Beaudoin, G. Skandan, T. Bowmer, I. Plitz, N. Pereira, T. Chapman, R. Jaworski, J. Electrochem. Soc., 148 (2001) A940.

[21] K. Xu, Y.F. Lam, S.S. Zhang, T.R. Jow, T.B. Curtis, J. Phys. Chem. C, 111 (2007) 7411-7421.

[22] N. Sa, T.L. Kinnibrugh, H. Wang, G. Sai Gautam, K.W. Chapman, J.T. Vaughey, B. Key, T.T. Fister, J.W. Freeland, D.L. Proffit, P.J. Chupas, G. Ceder, J.G. Bareno, I.D. Bloom, A.K. Burrell, Chem. Mater., 28 (2016) 2962-2969.

[23] J. Song, M. Noked, E. Gillette, J. Duay, G. Rubloffb, S.B. Lee, Phys. Chem. Chem. Phys., 17 (2015) 5256-5264.

[24] P. Novak, J. Desilves, J. Electrochem. Soc., 140 (1993) 140-144.

[25] L. Yu, X. Zhang, Journal of colloid and interface science, 278 (2004) 160-165.

[26] N. Sa, H. Wang, D.L. Proffit, A.L. Lipson, B. Key, M. Liu, Z. Feng, T.T. Fister, Y. Ren, C.-J. Sun, J.T. Vaughey, P.A. Fenter, K.A. Persson, A.K. Burrell, J. Power Sources, 323 (2016) 44-50.

[27] P.S.E. Yeo, M.-F. Ng, Chem. Mater., 27 (2015) 5878-5885.

[28] S. Yang, D. Li, T. Zhang, Z. Tao, J. Chen, J. Phys. Chem. C, 116 (2012) 1307-1312.

[29] S. Rasul, S. Suzuki, S. Yamaguchi, M. Miyayama, Electrochim. Acta, 82 (2012) 243-249. 
[30] V. Augustyn, J. Mater. Res., (in press) doi: 10.1557/jmr.2016.337 (2016).

[31] J. Yin, C.J. Pelliccione, S.H. Lee, E.S. Takeuchi, K.J. Takeuchi, A.C. Marschilok, J. Electrochem. Soc., 163 (2016) A1941-A1943.

[32] M. Inamoto, H. Kurihara, T. Yajima, Materials, 6 (2013) 4514-4522.

[33] P.E. Tang, J.S. Sakamoto, E. Baudrin, B. Dunn, J. Non-Cryst. Solids, 350 (2004) 6772.

[34] J. Livage, Chem. Mater., 3 (1991) 578-593.

[35] G.S. Gautam, P. Canepa, W.D. Richards, R. Malik, G. Ceder, Nano Lett., 16 (2016) 2426-2431.

[36] P. Novak, W. Scheifele, F. Joho, O. Haas, J. Electrochem. Soc., 142 (1995) 25442550.

[37] D.B. Le, S. Passerini, F. Coustier, J. Guo, T. Soderstrom, B.B. Owens, W.H. Smyrl, Chem. Mater., 10 (1998) 682-684.

[38] E.M. Guerra, K.J. Ciuffi, H.P. Oliveira, J. Solid State Chem., 179 (2006) 3814-3823.

[39] C.V.S. Reddy, J. Wei, Z. Quan-Yao, D. Zhi-Rong, C. Wen, S. Mho, R.R. Kalluru, Journal of Power Sources, 166 (2007) 244-249.

[40] D.L. Chao, X.H. Xia, J.L. Liu, Z.X. Fan, C.F. Ng, J.Y. Lin, H. Zhang, Z.X. Shen, H.J. Fan, Adv. Mater., 26 (2014) 5794-5800.

[41] F. Huguenin, R.M. Torresi, J. Phys. Chem. C, 112 (2008) 2202-2209.

[42] L. Shao, J.W. Jeon, J.L. Lutkenhaus, J. Mater. Chem. A, 1 (2013) 7648-7656.

[43] X. Rui, Z. Lu, Z. Yin, D.H. Sim, N. Xiao, T.M. Lim, H.H. Hng, H. Zhang, Q. Yan, Small, 9 (2013) 716-721.

[44] E. Cazzanelli, G. Mariotto, S. Passerini, W.H. Smyrl, J. Non-Cryst. Solids, 208 (1996) 89-98.

[45] L. Abello, E. Husson, Y. Repelin, G. Lucazeau, J. Solid State Chem., 56 (1985) 379389.

[46] X.Q. Liu, C.M. Huang, J.W. Qiu, Y.Y. Wang, Appl. Surf. Sci., 253 (2006) $2747-$ 2751.

[47] M. Stein, C.F. Chen, M. Mullings, D.J. Jamie, A. Zaleski, C.P. Rhodes, J. Electrochem. Energy Conv. Storage, 13 (2016) 031001.

[48] Z. Lu, A. Schechter, M. Moshkovich, D. Aurbach, J. Electroanal. Chem., 466 (1999) 203-217.

[49] T.T. Tran, W.M. Lamanna, M.N. Obrovac, J. Electrochem. Soc., 159 (2012) A2005A2009.

[50] F.J. Anaissi, G.J.F. Demets, E.B. Alvarez, M.J. Politi, H.E. Toma, Electrochim. Acta, 47 (2001) 441-450.

[51] D.B. Le, S. Passerini, J. Guo, J. Ressler, B.B. Owens, W.H. Smyrl, J. Electrochem. Soc., 143 (1996) 2099-2104.

[52] J.X. Wang, C.J. Curtis, D.L. Schulz, J.G. Zhang, J. Electrochem. Soc., 151 (2004) A1-A7.

[53] V. Petkov, P.N. Trikalitis, E.S. Bozin, S.J.L. Billinge, T. Vogt, M.G. Kanatzidis, J. Am. Chem. Soc., 124 (2002) 10157-10162.

[54] Y. Kim, Q.-T. Ta, H.-C. Dinh, P.K. Aum, I.-H. Yeo, W.I. Cho, S.-i. Mho, J. Electrochem. Soc., 158 (2011) A133.

[55] T. Yao, Y. Oka, N. Yamamoto, Mater. Res. Bull., 27 (1992) 669-675. 
[56] Y. Chen, G. Yang, Z. Zhang, X. Yang, W. Hou, J.J. Zhu, Nanoscale, 2 (2010) 21312138.

[57] Liu.Y.-J., S.J. L., D.D. C., K.C. R, H. W, K.M. G., Chem. Mater. , 8 (1996) 525-534.

[58] L. Abello, E. Husson, Y. Repelin, G. Lucazeau, Spectrochim. Acta Mol. Biomol. Spectrosc., 39 (1983) 641-651.

[59] C.J. Fontenot, J.W. Wiench, M. Pruski, G.L. Schrader, J. Phys. Chem. B, 105 (2001) 10496-10504.

[60] F. Leroux, G. Goward, W.P. Power, L.F. Nazar, J. Electrochem. Soc., 144 (1997) 3886-3895.

[61] J. Harreld, H.P. Wong, B.C. Dave, B. Dunn, L.F. Nazar, J. Non-Cryst. Solids, 225 (1998) 319-324.

[62] F.D. Hardcastle, I.E. Wachs, J. Phys. Chem., 95 (1991) 5031-5041.

[63] F. Huguenin, E.A. Ticianelli, R.M. Torresi, Electrochim. Acta, 47 (2002) 31793186.

[64] H. Matsuura, T. Miyazawa, Bull. Chem. Soc. Jpn., 41 (1968) 1798-1808.

[65] H. Matsuura, K. Fukuhara, J. Polym. Sci. B, 24 (1986) 1383-1400.

[66] I. Pucić, T. Jurkin, Radiation Physics and Chemistry, 81 (2012) 1426-1429.

[67] X. Li, S.L. Hsu, J. Polym. Sci. Pt. B-Polym. Phys., 22 (1984) 1331-1342.

[68] W. Wieczorek, D. Raducha, A. Zalewska, J.R. Stevens, J. Phys. Chem., 102 (1998) $8725-8731$.

[69] V.L. Volkov, G.S. Zakharova, L.A. Perelyaeva, Russ. J. Inorg. Chem., 51 (2006) 4145.

[70] N. Uchida, S. Kittaka, J. Phys. Chem., 98 (1994) 2129-2133.

[71] M.T. Vandenborre, R. Prost, E. Huard, J. Livage, Mater. Res. Bull., 18 (1983) 11331142.

[72] Y. Repelin, E. Husson, L. Abello, G. Lucazeau, Spectrochim. Acta Mol. Biomol. Spectrosc., 41 (1985) 993-1003.

[73] M. Giorgetti, S. Passerini, W.H. Smyrl, S. Mukerjee, X.Q. Yang, J. McBreen, J. Electrochem. Soc., 146 (1999) 2387-2392.

[74] D. Di Lecce, J. Hassoun, J. Phys. Chem. C, 119 (2015) 20855-20863. 
Figure 1. Graphical representation of growth of hydrated $\mathrm{V}_{2} \mathrm{O}_{5}$ nanosheet formation from water addition and condensation reactions of $\left[\mathrm{VO}_{4}\right]^{3-}$ polyanions in aqueous solution at low $\mathrm{pH}$; (a) without poly(ethylene oxide) (PEO); (b) with PEO.

Figure 2. Scanning electron microscopy (SEM) images of $\mathrm{V}_{2} \mathrm{O}_{5}$ xerogel (a), $\mathrm{V}_{2} \mathrm{O}_{5}$-PEO-1 (b), and $\mathrm{V}_{2} \mathrm{O}_{5}$-PEO-2 nanocomposite (c); Transmission electron microscopy (TEM) images of $\mathrm{V}_{2} \mathrm{O}_{5}$ xerogel (d), $\mathrm{V}_{2} \mathrm{O}_{5}$-PEO-1 (e), and $\mathrm{V}_{2} \mathrm{O}_{5}$-PEO-2 nanocomposite (f); Highresolution TEM images showing $d$-spacings of $\mathrm{V}_{2} \mathrm{O}_{5}$ xerogel $(\mathrm{g}), \mathrm{V}_{2} \mathrm{O}_{5}$-PEO-1 (h), and $\mathrm{V}_{2} \mathrm{O}_{5}-\mathrm{PEO}-2$ nanocomposite (i).

Figure 3. Energy dispersive spectroscopy (EDS) elemental mapping of $\mathrm{V}_{2} \mathrm{O}_{5}-\mathrm{PEO}-1$ nanocomposite; (a) SEM image; corresponding EDS mappings of (b) carbon (C), (c) vanadium $(\mathrm{V})$, and (d) oxygen $(\mathrm{O})$ elements of $\mathrm{V}_{2} \mathrm{O}_{5}$-PEO-1.

Figure 4. (a) X-Ray diffraction (XRD) powder patterns of $\mathrm{V}_{2} \mathrm{O}_{5}$ xerogel, $\mathrm{V}_{2} \mathrm{O}_{5}-\mathrm{PEO}-1$, and $\mathrm{V}_{2} \mathrm{O}_{5}$-PEO-2 nanocomposite; (b) Expanded region from $2 \theta^{\circ}=\sim 5-10$ showing shifting of the (001) peak to lower $2 \theta^{\circ}$ values upon introduction of PEO.

Figure 5. a) ATR-FTIR spectra of $\mathrm{V}_{2} \mathrm{O}_{5}$ xerogel, $\mathrm{V}_{2} \mathrm{O}_{5}$-PEO nanocomposites, and PEO; Bands corresponding to $\mathrm{C}-\mathrm{O}-\mathrm{C}, \mathrm{C}-\mathrm{H}$ and $v_{\mathrm{s}}\left(\mathrm{V}=\mathrm{O}_{\mathrm{A}}\right)$ stretches are labeled; inset figure shows the expanded region from $\sim 1020-1170 \mathrm{~cm}^{-1}$ corresponding to the C-O-C stretching bands; (b) Expanded region from $800-1100 \mathrm{~cm}^{-1}$ showing the $v_{\mathrm{s}}(\mathrm{V}=\mathrm{O})$ downshift. 
Figure 6. (a) Raman spectra of $\mathrm{V}_{2} \mathrm{O}_{5}$ xerogel, $\mathrm{V}_{2} \mathrm{O}_{5}-\mathrm{PEO}-1$ and $\mathrm{V}_{2} \mathrm{O}_{5}-\mathrm{PEO}-2$ in the 100 $\mathrm{cm}^{-1}$ to $950 \mathrm{~cm}^{-1}$ region; (b) Representation of possible coordination of interlayer $\mathrm{H}_{2} \mathrm{O}$ within $\mathrm{V}_{2} \mathrm{O}_{5}$ via hydrogen bonding; (c) Representation of possible coordination of $\mathrm{V}_{2} \mathrm{O}_{5}$ with both interlayer $\mathrm{H}_{2} \mathrm{O}$ and $\mathrm{PEO}$ via hydrogen bonding; schematics do not represent steric effects and PEO chain conformation.

Figure 7. Galvanostatic charge-discharge voltage profiles of $\mathrm{V}_{2} \mathrm{O}_{5}, \mathrm{~V}_{2} \mathrm{O}_{5}-\mathrm{PEO}-1$ and $\mathrm{V}_{2} \mathrm{O}_{5}$-PEO-2 acquired at a mass-normalized current of $10 \mathrm{~mA} \mathrm{~g}^{-1}$; electrolyte: $1 \mathrm{M}$ $\mathrm{Mg}\left(\mathrm{ClO}_{4}\right)_{2}$ in dried acetonitrile; counter: carbon; reference: $\mathrm{Mg}$ metal.

Figure 8. (a) Cyclic voltammograms of $\mathrm{V}_{2} \mathrm{O}_{5}, \mathrm{~V}_{2} \mathrm{O}_{5}$-PEO-1 and $\mathrm{V}_{2} \mathrm{O}_{5}$-PEO-2 recorded at a scan rate of $2.5 \mathrm{mV} / \mathrm{s}$; electrolyte: $1 \mathrm{M} \mathrm{Mg}\left(\mathrm{ClO}_{4}\right)_{2}$ in dried acetonitrile; counter: carbon cloth; reference: $\mathrm{Mg}$ metal; (b) Plot of the peak current density as a function of the square root of scan rate $(v)$ showing a linear response (c) Cycling performance of $\mathrm{V}_{2} \mathrm{O}_{5}$, $\mathrm{V}_{2} \mathrm{O}_{5}$-PEO-1 and $\mathrm{V}_{2} \mathrm{O}_{5}$-PEO-2 recorded at $10 \mathrm{~mA} / \mathrm{g}$ constant current density for 30 cycles. All electrodes were pre-conditioned by charging and discharging 5 cycles prior to cycling. 
Graphical abstract

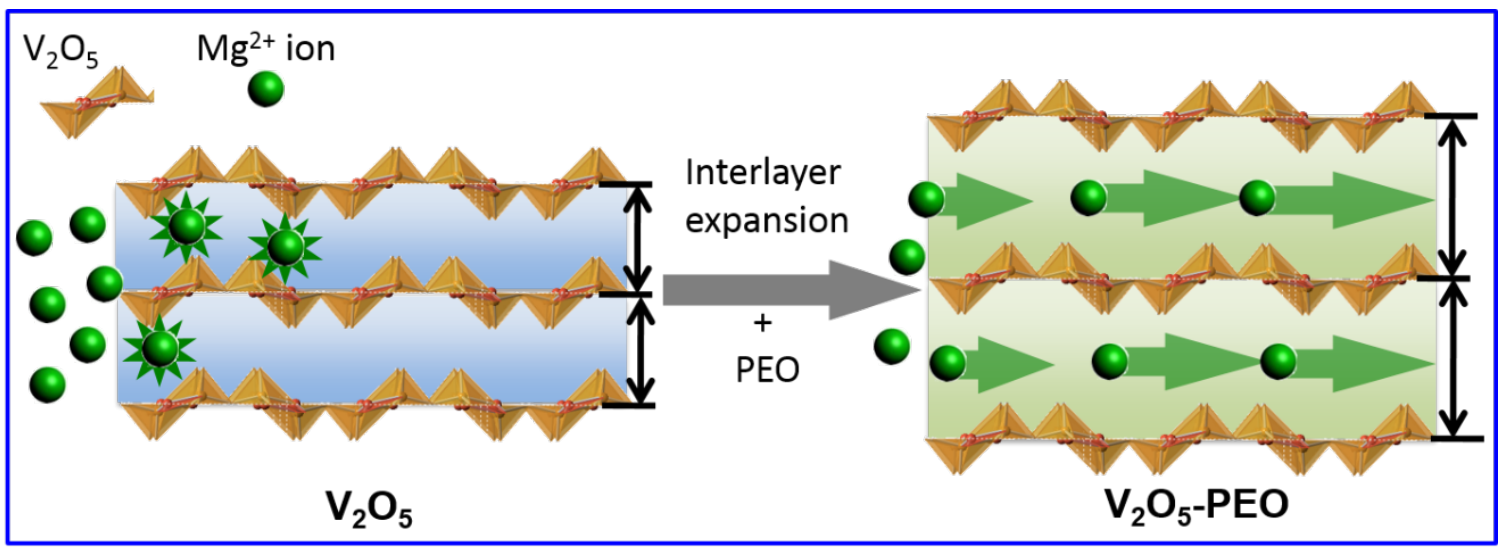

